\author{
UNIVERSIDADE DE BRASÍLIA \\ FACULDADE DE EDUCAÇÃO FÍSICA \\ PROGRAMA DE PÓS-GRADUAÇÃO STRICTO SENSU EM EDUCAÇÃO \\ FÍSICA
}

\title{
ASSOCIAÇÕES ENTRE COMPOSIÇÃO CORPORAL, PICO DE TORQUE, FADIGA E DISTRESS PSICOLÓGICO EM SOBREVIVENTES DE LINFOMA DE HODGKIN
}

Lorena Cruz Resende 


\title{
ASSOCIAÇÕES ENTRE COMPOSIÇÃO CORPORAL, PICO DE TORQUE, FADIGA E DISTRESS PSICOLÓGICO EM SOBREVIVENTES DE LINFOMA DE HODGKIN
}

\author{
Lorena Cruz Resende
}

Dissertação de mestrado apresentada ao Programa de Pós-graduação Stricto Sensu da Faculdade de Educação Física da Universidade de Brasília como requisito para a obtenção do Grau de Mestre em Educação Física.

ORIENTADOR: PROF. DR. RICARDO JACÓ DE OLIVEIRA 
Ficha catalográfica elaborada automaticamente, com os dados fornecidos pelo(a) autor(a)

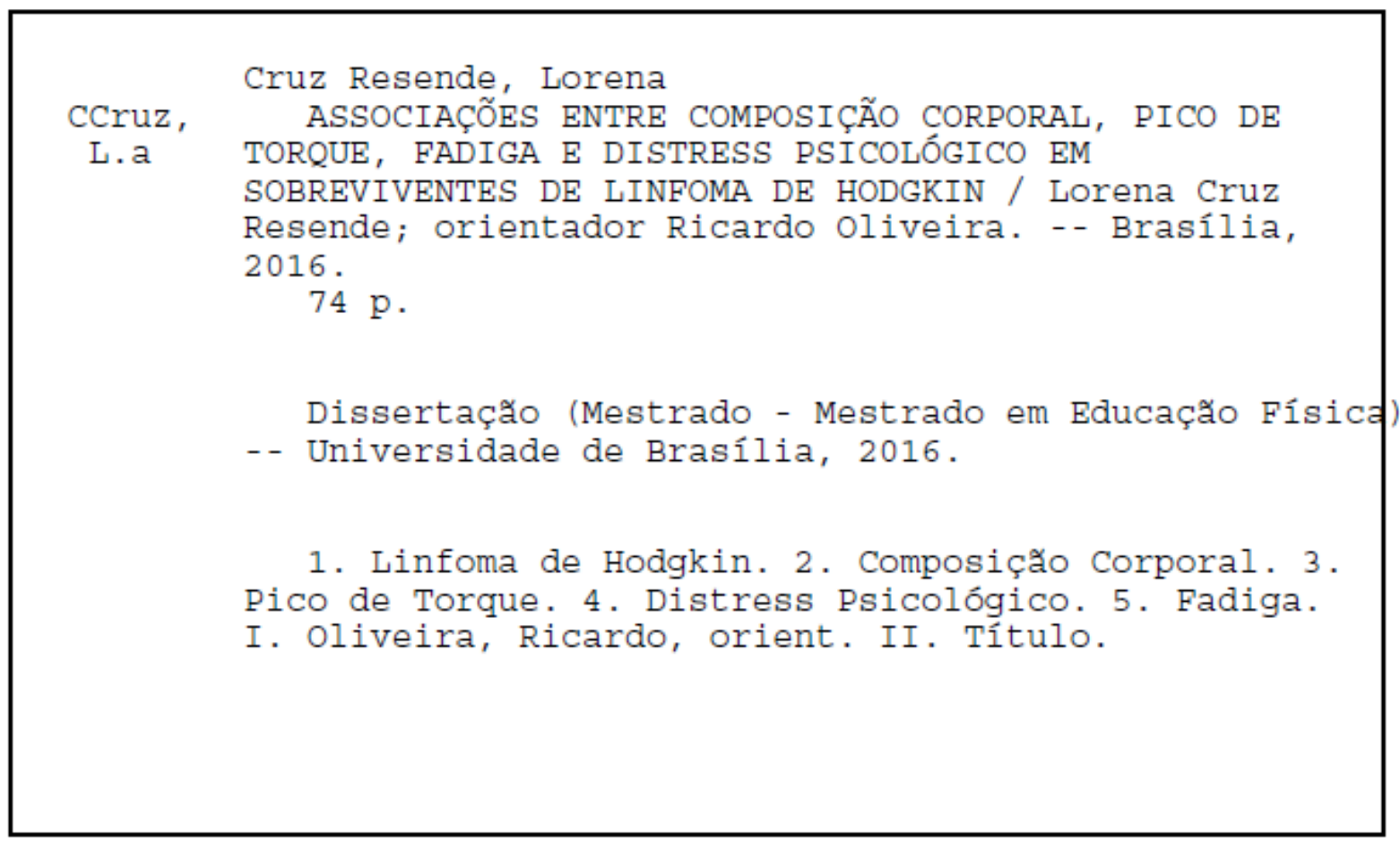




\section{EPÍGRAFE}

Se

Se és capaz de manter a tua calma quando Todo o mundo ao teu redor já a perdeu e te culpa;

De crer em ti quando estão todos duvidando, E para esses no entanto achar uma desculpa; Se és capaz de esperar sem te desesperares, Ou, enganado, não mentir ao mentiroso, Ou, sendo odiado, sempre ao ódio te esquivares, E não parecer bom demais, nem pretensioso;

Se és capaz de pensar --sem que a isso só te atires, De sonhar --sem fazer dos sonhos teus senhores. Se encontrando a desgraça e o triunfo conseguires Tratar da mesma forma a esses dois impostores; Se és capaz de sofrer a dor de ver mudadas Em armadilhas as verdades que disseste, $E$ as coisas, por que deste a vida, estraçalhadas, E refazê-las com o bem pouco que te reste;

Se és capaz de arriscar numa única parada Tudo quanto ganhaste em toda a tua vida, E perder e, ao perder, sem nunca dizer nada, Resignado, tornar ao ponto de partida;

De forçar coração, nervos, músculos, tudo A dar seja o que for que neles ainda existe, E a persistir assim quando, exaustos, contudo Resta a vontade em ti que ainda ordena: "Persiste!";

Se és capaz de, entre a plebe, não te corromperes $E$, entre reis, não perder a naturalidade, E de amigos, quer bons, quer maus, te defenderes, Se a todos podes ser de alguma utilidade, E se és capaz de dar, segundo por segundo, Ao minuto fatal todo o valor e brilho,

Tua é a terra com tudo o que existe no mundo E o que mais --tu serás um homem, ó meu filho!

Rudyard Kipling 


\section{DEDICATÓRIA}

Dedico este trabalho aos amantes do conhecimento, aos exploradores da ciência, aos que não desistem frente aos obstáculos que uma pesquisa (sempre) tem.

Dedico este trabalho aos sobreviventes de câncer, na esperança de que estes esforços possam fazer diferença na promoção de saúde e cuidados desta população. 


\section{AGRADECIMENTOS}

À minha mãe (in memoriam), Taisa Helena da Cruz, por absolutamente tudo, mas é tudo mesmo. É impossível resumir em algumas palavras, mais difícil ainda conceituar o que você foi, o que representa, o que significa, o que me proporcionou. Obrigada pela sua existência, pela educação que me deu, por me ensinar a superar desafios, por superar seus próprios desafios e ser o meu exemplo. Amo você, como todo meu ser, para sempre.

À minha vó Cidinha (Conceição Aparecida Cruz) por ter exercido o ofício de "porto seguro" com tanto amor e dedicação, por ter sido responsável por tantos pontos de luz na minha vida. Por ter me dado minha mãe e, ainda, meu padrinho e madrinhas.

Ao Rodrigo Soares, pelo seu amor e dedicação. Por ter me segurado antes que eu caísse, por ter me levantado quando a queda era inevitável. Pela Lilica e pela Luna. Por formatar meu computador, por instalar o que eu precisava, por trocar o chuveiro, por concordar - ainda que com resistência - que $700 \mathrm{~km}$ é logo ali. Por descer com a Lilica, pelas aulas de luta, pelas tardes de vídeo game, por lavar a louça, por me aguentar falar tanto sobre tanto. Por me implicar, inclusive, enquanto eu tentava escrever meus agradecimentos a você.

À Riti (Ritielli de Oliveira Valeriano) meu sincero, enorme e eterno agradecimento, pelo acolhimento, pelo voto de confiança, pela amizade, pelas ideias e sugestões, pela escuta, pela percepção dos trejeitos, e, claro, por ter permitido que minha pesquisa se realizasse sob suas asas.

Ao Filipe Dinato de Lima, por ter somado tanto ao nosso grupo, pelos conhecimentos, ideias e escritas.

À professora Lídia Bezerra, pelas parcerias, pelas aulas, pelas oportunidades de aprendizado em tantas áreas, pela confiança no meu trabalho, pelas conversas e conselhos e pelas aulas de yoga que você ainda me deve.

Ao professor Claudio Battaglini, por todas as sugestões e correções, pelo interesse em contribuir com os trabalhos de nossa equipe. 
Ao professor Martin Bottaro, por disponibilizar seus equipamentos e o laboratório de força para que pudéssemos realizar nossas coletas.

À Lilica e Luna, pelo companheirismo, pelas alegrias, pelo amor incondicional que só suas espécies podem proporcionar.

À Faculdade de Educação Física por ter sido um segundo lar, por ter me acolhido lá em 2009 como caloura no Curso de Educação Física. Nossa relação de amor e cansaço, alegrias e fome me proporcionaram oportunidades e aprendizados impagáveis.

À CAPES pelo financiamento da bolsa de estudos concedida ao programa da faculdade.

E ao meu orientador, Ricardo Jacó de Oliveira, agradeço por todas as oportunidades e votos de confiança que o senhor me conferiu desde 2011, desde que me aceitou como colaboradora do projeto de parkinson. Tive oportunidades e vivências de suma importância - pessoal e profissional - sob sua orientação, reconheço cada uma delas e serei eternamente grata por elas, que me trouxeram até aqui. Todo o meu reconhecimento e agradecimento eu dedico a você que durante tantos anos aprendeu para ensinar; que com toda a dedicação, empenho e paciência ajudou a preparar as mentes do futuro, inspirando seus alunos a aprenderem, a descobrirem, mas também thes fornecendo bases para que se tornassem melhores pessoas. Não conseguiria retribuir em Terra tudo o que o senhor me proporcionou e me ensinou, apenas posso me expressar através da limitação de meras palavras, e com elas Ihe prestar este humilde, mas sincero agradecimento. 


\section{RESUMO}

Linfoma de Hodgkin é um câncer hematológico que atinge o sistema linfático, os tratamentos que o combatem são citotóxicos e trazem efeitos colaterais pontuais e tardios que podem alterar a composição corporal, níveis de força e tecido muscular, e essas alterações estariam associadas à fadiga oncológica e ao distresse psicológico ao sobrevivente desta doença. Estas alterações levariam o sobrevivente a um pior prognóstico e à uma pior qualidade de vida em sua sobrevida. Objetivo: Verificar associações da composição corporal e do pico de torque com as variáveis fadiga e distress psicológico em sobreviventes de LH e compará-las a pessoas aparentemente saudáveis. Materiais e Métodos: 12 sobreviventes de linfoma de Hodgkin (GL: $31,75 \pm 7,99$ anos), que concluíram o tratamento há mais de seis meses e 79 indivíduos aparentemente saudáveis como grupo controle (GC: 31,48 \pm 8,02 anos) foram submetidos a avaliação subjetiva de fadiga (IMF-20), distress psicológico, análise da composição corporal e mensuração do pico de torque isocinético da extensão de joelho a $60^{\circ} . \mathrm{s}^{-1}$. Média e desvio padrão das variáveis foram feitas para estatística descritiva, enquanto a comparação das variáveis entre os dois grupos foi feita através do teste $T$ de student para amostras independentes - que apresentaram normalidade - e teste Wilcoxon-Mann-Whitney para amostras que não apresentarem distribuição normal. Sendo assim, para as variáveis que apresentaram normalidade, a correlação foi feita usando teste de Pearson (r), enquanto as variáveis nãoparamétricas foram correlacionadas através do teste de Spearman $O$ cálculo do tamanho do efeito das estatísticas descritivas foi obtido através do teste de Cohen (d). Resultados: Apenas o percentual de gordura, fadiga geral e fadiga mental foram significativamente maiores no GL. Houve correlações significativas para ० GL nas variáveis pico de torque absoluto e relativo com a composição corporal, distress psicológico e fadiga. Conclusão: Os resultados desse estudo confirmam que os sobreviventes de LH possuem maior percentual de gordura, maiores níveis de fadiga e maior distresse psicológico que o GC; possuem uma frequência maior de preocupações com problemas de ordem de saúde e do cotidiano. No entanto, um maior percentual de gordura parece não se associar com os índices de fadiga e distresse relatados pelo GL, seus os níveis de força parecem ser apenas parcialmente associados aos domínios da fadiga, porém, estão negativamente relacionados ao percentual de gordura. 


\begin{abstract}
Hodgkin's Lymphoma is a hematological cancer that affects the lymphatic system, its treatments are cytotoxic and bring punctual and late side effects that can alter body composition, strength levels and muscle tissue, and these changes would be associated with cancer fatigue and psychological distress to cancer survivors. These changes would lead to a worse prognosis and a worse quality of life. Objective: To verify associations of body composition and peak torque with the variables fatigue and psychological distress in LH survivors and compare them to apparently healthy people. Methods: 12 Hodgkin's lymphoma survivors (GL: $31.75 \pm 7.99$ years), who have completed treatment for more than six months and 79 apparently healthy individuals as a control group (CG: $31.48 \pm 8.02$ years) underwent subjective assessment of fatigue (MFI-20), psychological distress, body composition analysis and measurement of peak torque isokinetic knee extension to $60^{\circ} \mathrm{s}^{-1}$. Mean and standard deviation were made with descriptive statistics, while the comparison of the variables between the two groups was performed using the Student's $T$ test for independent samples and Wilcoxon $\mathrm{T}$ test for samples that do not show normal distribution. Thus, correlations were performed using the Pearson test $(r)$, while non-parametric variables were correlated using the Spearman test The calculation of the effect size of descriptive statistics were obtained through the Cohen's test (d). Results: Only fat percentage, general fatigue and mental fatigue were significantly higher in the GL. There were significant correlations for the $\mathrm{GL}$ in absolute and relative torque peaks variables to body composition, psychological distress and fatigue. Conclusion: Results of this study confirm that LH survivors have a higher fat percentage, higher levels of fatigue and greater psychological distress than the GC; They have a higher frequency of concerns about their health and daily life activities. However, a higher percentage of fat does not seem to be associated with fatigue indices and distress reported by GL, their strength levels seem to be only partially associated with the areas of fatigue, however, are negatively related to the percentage of fat.
\end{abstract}




\section{SUMÁRIO}

1. INTRODUÇÃO

2. OBJETIVOS 17

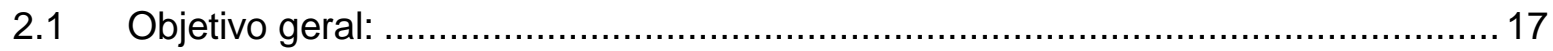

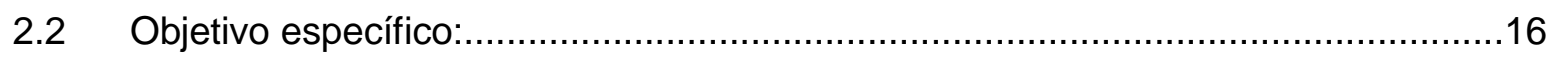

3. REVISÃO DE LITERATURA $\quad 18$

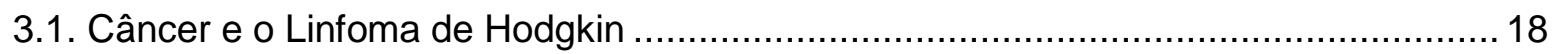

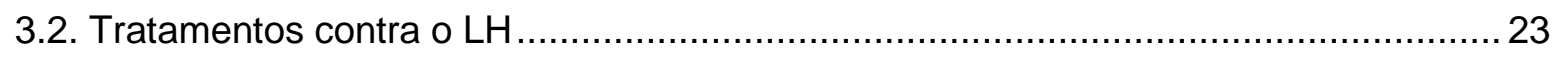

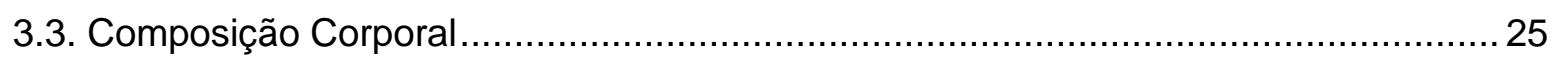

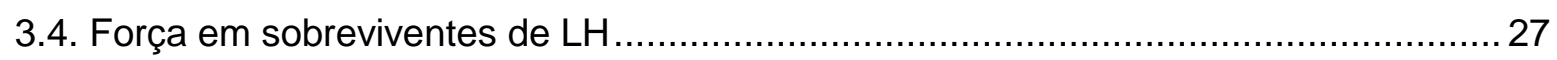

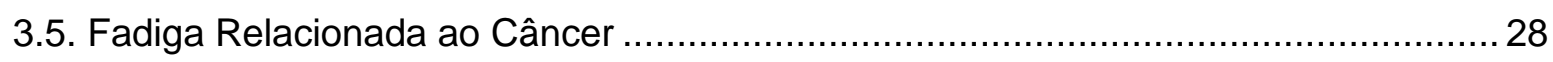

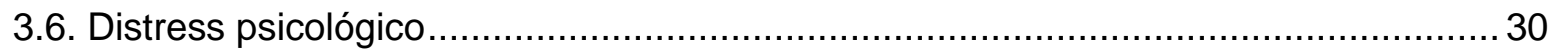

4. MATERIAIS E MÉTODOS: 33

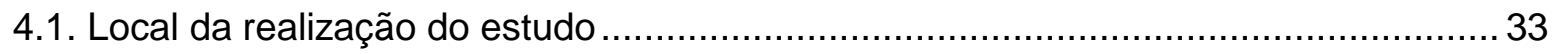

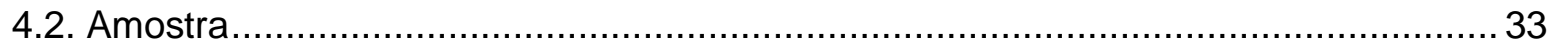

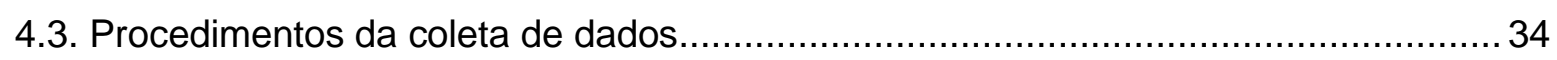

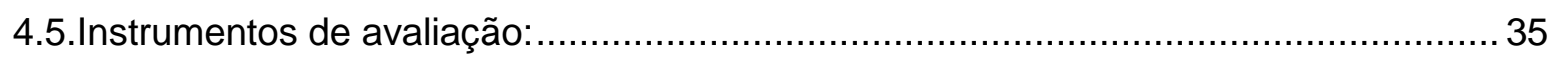

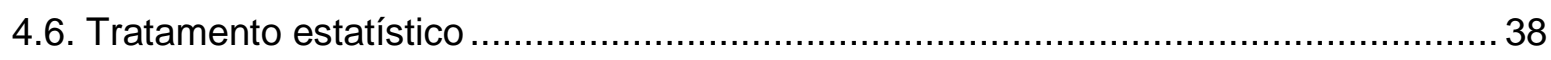

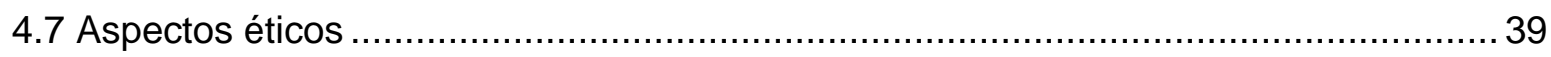

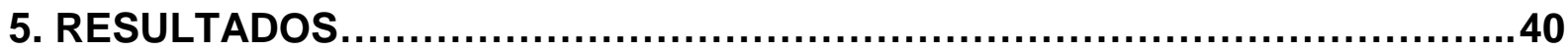

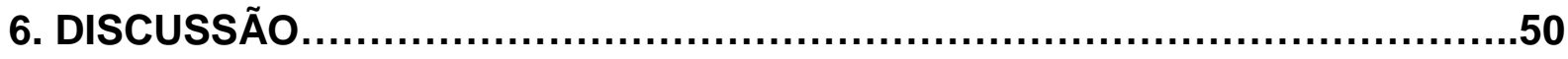

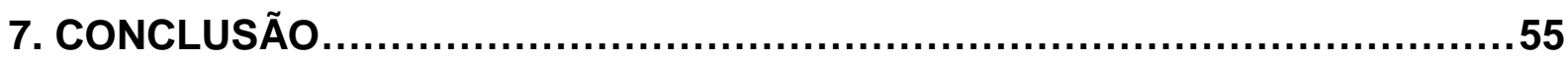

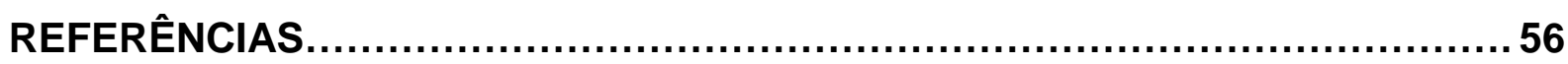

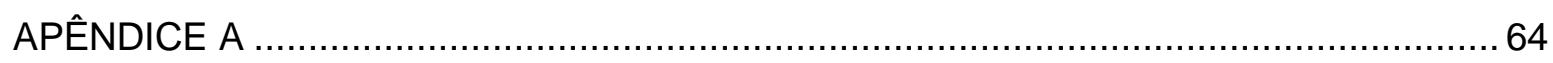

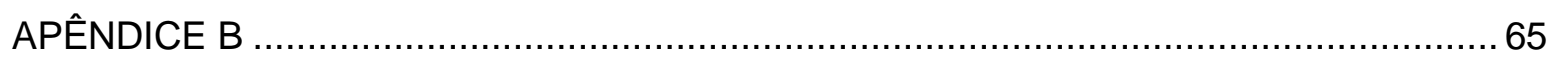

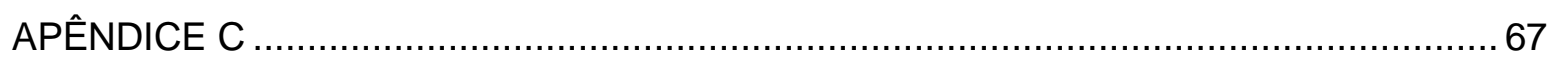

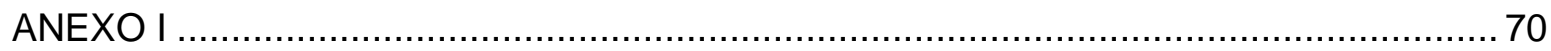

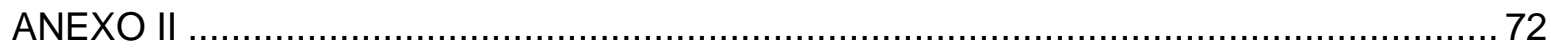




\section{LISTA DE FIGURAS}

Figura 1 - Célula de Reed-Sternberg binucleada...............................................20

Figura 2 - Regiões envolvidas no linfoma de Hodgkin de acordo com o Sistema de

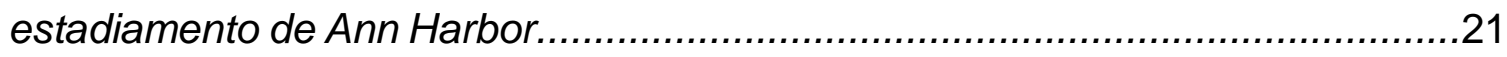

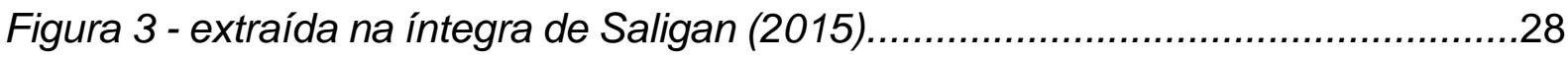




\section{LISTA DE TABELAS}

Tabela 1 - Caracterização dos participantes do estudo, para o grupo linfoma (GL) e grupo controle (GC), utilizando-se média, desvio padrão (DP), comparação entre as médias e tamanho do efeito (ES).

Tabela 2 - Dados descritivos utilizando-se média, desvio padrão (DP), comparação entre as médias e tamanho do efeito (ES) do PT, PTR, distresse psicológico, fadiga geral, fadiga física, fadiga mental, redução de atividade e redução da motivação para o GL e para o GC.

Tabela 3 - Dados descritivos e frequências dos domínios do instrumento Termômetro de Distresse; Domínio Problemas Práticos.

Tabela 4 - Dados descritivos e frequências dos domínios do instrumento Termômetro de Distresse; Domínio Problemas Familiares.

Tabela 5 - Dados descritivos e frequências dos domínios do instrumento Termômetro de Distresse; Domínio Envolvimento espiritual/religioso.

Tabela 6 - Dados descritivos e frequências dos domínios do instrumento Termômetro de Distresse; Domínio Problemas Emocionais.

Tabela 7 - Tabela 7- Dados descritivos e frequências dos domínios do instrumento Termômetro de Distresse; Domínio Problemas Físicos.

Tabela 8 - Dados das correlações entre composição corporal e as variáveis fadiga e distresse psicológico do GL.

Tabela 9 - Dados das correlações entre composição corporal e as variáveis fadiga e distresse psicológico do GC.

Tabela 10 - Dados das correlações entre PT e PTR e as variáveis fadiga e distresse psicológico do GL

Tabela 11 - Dados das correlações entre PT e PTR e as variáveis fadiga e distress psicológico do GC.

Tabela 12 - Dados das correlações entre PT e PTR e composição corporal dos grupos Linfoma e Controle. 50

Tabela 13 - Dados das correlações entre Distress psicológico e os domínios da variável fadiga dos grupos Linfoma e Controle. 50 


\section{LISTA DE ABREVIATURAS E SIGLAS}

$\begin{array}{ll}\text { ABVD } & \text { Adriamicina, bleomicina, vinblastina e dacarbazina } \\ \text { ACSM } & \text { American College of Sports Medicine } \\ \text { CEP } & \text { Comitê de Ética em Pesquisa } \\ \text { DF } & \text { Distrito Federal } \\ \text { VEB } & \text { Vírus Epstein-Barr } \\ \text { FEF } & \text { Faculdade de Educação Física } \\ \text { FS } & \text { Faculdade de Ciências da Saúde } \\ \text { FRC } & \text { Fadiga Relacionada ao Câncer } \\ \text { GC } & \text { Grupo Controle } \\ \text { GL } & \text { Grupo Linfoma } \\ \text { IAC } & \text { Índice de Adiposidade Corporal } \\ \text { IF } & \text { Índice de Fadiga } \\ \text { IMC } & \text { Índice de Massa Corporal } \\ \text { IMF-20 } & \text { Inventário Multidimensional de Fadiga } \\ \text { INCA } & \text { INSTITUTO NACIONAL DE CÂNCER } \\ \text { IPAQ } & \text { Questionário Internacional de Atividade Física } \\ \text { LH } & \text { Linfoma de Hodgkin } \\ \text { MOPP } & \text { Mecloretamina, Oncovin [vincristina], Prednisona e Procarbazina } \\ \text { NCCS } & \text { National Coalition for Cancer Survivorship } \\ \text { Nm } & \text { Newton metro } \\ \text { PT } & \text { Pico de torque } \\ \text { PTR } & \text { Pico de Torque Relativo } \\ \text { RS } & \text { Reed-Stenberg } \\ \text { SES } & \text { Secretaria de Saúde } \\ \text { TCLE } & \text { Termo de Consentimento Livre e Esclarecido } \\ \text { TD } & \text { Universidade de Brasília } \\ \text { UnB } & \end{array}$




\section{INTRODUÇÃO}

Segundo Siegel (2011), câncer é a maior causa de mortalidade para pessoas com menos de 85 anos de idade, ultrapassando as mortes relacionadas a doenças cardiovasculares. Por sua vez, o linfoma de Hodgkin (LH) é um dos vários tipos de câncer que acomete o sistema hematológico e age especificamente no sistema linfático (KÜPPERS, 2009), estando entre os dois tipos mais comuns de linfoma, juntamente com o linfoma não-Hodgkin (SMITH, 2005). No Brasil, para o biênio de 2014/2015, estimou-se 2.180 novos casos de LH entre homens e mulheres (INCA, 2014). Por outro lado, o diagnóstico precoce e a terapêutica adequada permitem aos indivíduos acometidos pela doença uma taxa de sobrevida de $88 \%$ (SIEGEL, 2015). Para além disso, com os contínuos avanços no tratamento de indivíduos com $\mathrm{LH}$, esses tendem a sobreviver várias décadas após o seu término (SPECTOR, 2004).

Para tratar a doença se combinam alguns tratamentos médicos e farmacológicos. Dentre os tratamentos disponíveis contra o câncer estão a quimioterapia, a radioterapia. Porém, apesar dos enormes avanços médicos no rastreamento e tratamento dessa forma de câncer, os sobreviventes têm de conviver com os efeitos colaterais das terapias antineoplásicas (AMERICAN CANCER SOCIET, 2013).

Estudos mostram que as terapias anticâncer causam várias complicações a curto e longo prazo, por serem extremamente tóxicas ao organismo e por causarem desequilíbrios diversos à sua fisiologia. Dentre os efeitos colaterais, a curto e longo prazo, comumente relatados pela literatura há fatores psicológicos como déficit cognitivo, distresse psicológico, ansiedade, depressão e problemas psicossociais; perda de massa magra e perda de força e funcionalidade, aumento da incidência de sobrepeso e obesidade, diminuição da densidade mineral óssea (DMO), e neuropatia periférica, entre outros efeitos tanto pontuais quanto tardios, capazes de comprometer o funcionamento de muitos sistemas fisiológicos, ressaltando que a fadiga, relatada como Fadiga Relacionada ao Câncer (FRC) representa um dos grandes desafios dessa doença, chegando a acometer $85 \%$ dos sobreviventes de câncer e podendo persistir por mais de dez anos como um sintoma debilitante. (CELLA, 1986; 
HOLLEY,2000; BROWN, 2009; BROWN E KROENKE, 2009; HEUTTE, 2009; LEEUWEN-SEGARCEANU, 2012; SHEPPARD, 2013; SIMÃO, 2015; LAVOY, 2016).

Mudanças metabólicas e na composição corporal são muito frequentes em pessoas tratadas de câncer, e geralmente ocorrem em períodos muito curto de tempo, assim, os sobreviventes apresentaram alterações médias não favoráveis substanciais nos componentes da composição corporal (aumento percentual de gordura corporal, perda de tecido muscular esquelético e diminuição da densidade mineral óssea) antes e ao longo do tratamento quimioterápico e/ou radioterápico e essas alterações negativas persistirão por anos após a conclusão do tratamento (DEMARKWAHNEFRIED ET AL., 2002; MAKARI-JUDSON ET AL., 2007; CHEN ET AL., 2010; THIVAT ET AL., 2010; YAW ET AL., 2010; THIBAULT ET AL., 2012). Não sendo, ainda, claros quais os mecanismos que conduziriam a estas alterações.

Tratamentos anticâncer tem ação tóxica no organismo, causam alterações metabólicas e endócrinas que, dentre outros efeitos colaterais, estão relacionadas à depleção sistema muscular, além dos prejuízos causados a outros órgãos e sistemas como fígado, rins, coração, intestinos e tecido adiposo (WOLFE, 2006; MULROONEY, 2012; SHEPPARD, 2013; ARGILES, 2014). A perda acentuada de tecido muscular é denominada caquexia, ação concomitantemente associada à perda de força, o que, consequentemente, interfere na qualidade de vida do indivíduo acometido e, ainda, piora seu prognóstico na sobrevida (TISDALE, 2002; RUTTEN, 2016).

Os níveis de mortalidade em câncer estão diretamente relacionados à composição corporal. Obesidade e caquexia contribuem para uma menor taxa de sobrevivência e uma pior qualidade de vida do indivíduo, apesar dos mecanismos de ação dos componentes da composição corporal ainda serem incertos (RUTTEN, 2016).

A National Comprehensive Cancer Network (NCCN) e a American Psychosocial Oncology Society, a partir de 1997, determinaram o uso do termo distresse para se referir ao sofrimento emocional vivenciado pelo paciente oncológico, pois este termo caracteriza adequadamente os aspectos psicossociais durante 0 tratamento do câncer. O termo é definido, portanto, como uma "experiência emocional desagradável e multifatorial, de natureza psicológica (cognitiva, comportamental e emocional), social ou espiritual, que interfere na capacidade de lidar eficazmente com 
o câncer, suas alterações físicas, sintomas e tratamento". Além disto, emoções como medo, raiva, ressentimento, agressividade, depressão, extrapolam a capacidade de controle (eustresse), tornando o estresse negativo (distresse) um problema para o indivíduo com câncer, sobrepondo, substancialmente, sua capacidade de enfrentamento de situações difíceis (HOLLAND, 2007; DE ALBUQUERQUE 2010).

O distresse psicológico é um sintoma comum entre pacientes oncológicos (CARLSON, 2003), além de abranger sentimento de tristeza, medo, depressão e ansiedade e tem sido associado à fatores e sintomas físicos como dor e fadiga (NCCN GUIDELINES, 2012). As respostas fisiológicas ao distresse, como maior liberação de cortisol, podem gerar respostas comportamentais negativas, interferindo na qualidade de vida do paciente e, até mesmo, na aderência ao tratamento e aos cuidados oncológicos (TALARICO, 2010; KIM, 2011).

Ademais, sobreviventes de linfoma parecem apresentar sintomas de distresse físico e emocional mesmo após o término do tratamento primário e o tempo decorrido desde o diagnóstico parece não ser o principal fator dessa prevalência. Além disso, tais sintomas parecem persistir mesmo quando não há mais os efeitos estressores relacionados à doença (DEIMLIN, 2002; JONES, 2015). E, ainda, mulheres parecem ser mais afetadas por este sintoma, enquanto a falta de suporte social e familiar e baixo nível de escolaridade, estão associados a um maior nível de distresse psicológico (MORASSO, 2010).

A Fadiga Relacionada ao Câncer (FRC) é um dos principais e dos mais debilitantes sintomas experienciados por sobreviventes de câncer, está presente em cerca de $70 \%$ dos sobreviventes e se mantém presente tanto durante o tratamento quanto anos após seu término (SMETS, 1993; SMETS, 1995). A FRC é um sintoma multidimensional, que traz a sensação de cansaço, exaustão ou esgotamento, sem motivo aparente e que não melhora com repouso ou sono, o que implica vários domínios da qualidade de vida relacionada à saúde (QVRS) do sobrevivente, afetando-o fisicamente, mentalmente, e, ainda, diminuem sua motivação e suas atividades da vida diária (SMETS, 1993; BARSEVICK, 2010).

Em seu estudo, Okuyama (2000) corrobora com Bower (2000) ao relatar que encontrou correlação significativa entre depressão e todas as dimensões de 
fadiga e afirmar que a fadiga para esta população parece estar mais relacionada ao distresse físico e psicológico que à doença em si e seus tratamentos.

Em seu estudo, Stone (2001) aponta que a FRC pode estar associada ao estado de estresse, pois encontrou associação significativa entre severidade da fadiga e estresse psicológico, náusea, dor, dispneia dentre outros sintomas de efeitos colaterais do tratamento radioterápico, mas a maior associação foi entre a severidade da fadiga e depressão.

O caminho patológico desta condição ainda é incerto (GUTSTEIN, 2001). Há estudos que visam verificar a existência da fadiga periférica, cuja origem estaria diretamente no tecido muscular e no seu metabolismo, ao passo que outros estudos defendem a origem desse sintoma como alguma disfunção do Sistema Nervoso Central (SNC) (RYAN, 2007).

Neste sentido, devido à escassez de estudos avaliando e associando estas variáveis, acredita-se haver a necessidade de investigação acerca destas variáveis e suas associações no intuito de haver melhor entendimento de seus mecanismos e, assim, haver a possibilidade de melhor manejo e intervenções acerca de seu comportamento. Pois, desta forma, seria possível promover melhor qualidade de vida ao sobrevivente e promoção de educação em saúde à equipe multidisciplinar envolvida em todo processo de intuito curativo. 


\section{OBJETIVOS}

\subsection{Objetivo geral:}

Verificar associações da composição corporal e do pico de torque com as variáveis fadiga e distress psicológico em sobreviventes de LH.

\subsection{Objetivo específico:}

Comparar os resultados obtidos pela população de sobreviventes de $\mathrm{LH}$ e compará-las a pessoas aparentemente saudáveis. 


\section{REVISÃO DE LITERATURA}

\subsection{Câncer e o Linfoma de Hodgkin}

Câncer é o nome dado a um conjunto de mais de 100 doenças que têm em comum o crescimento desordenado (maligno) de células que invadem os tecidos e órgãos, podendo espalhar-se (metástase) para outras regiões do corpo. Dentre esses diversos tipos de câncer há o linfoma de Hodgkin (LH), um tipo de câncer que compõe o grupo de cânceres hematológicos e define-se como uma neoplasia do tecido linfoide, é assim chamado porque foi descrito pela primeira vez, em 1832, por Thomas Hodgkin. Segundo Lopes (2006), o LH corresponde a menos de 1\% dos novos casos de câncer no Brasil e a cerca de 30\% de todos os linfomas, com uma incidência, aparentemente, estável. Pessoas de todas as idades são acometidas por esse tipo de linfoma, que segue uma distribuição etária bifásica, cujo primeiro pico de incidência ocorre entre os 14 e 40 anos e o segundo pico, em adultos com mais de 50 anos, sendo mais comum em homens do que em mulheres (SMITH, 2005; RODAK, 2005).

O tecido afetado pelo $\mathrm{LH}$ tem presente as chamadas células de ReedSternberg e/ou células de Hodgkin, caracterizadas por uma infiltração heterogênea de células anormalmente grandes, que podem ser mono, bi e/ou multinucleadas, inseridas num contexto inflamatório próprio constituído por estroma, linfócitos, histiócitos, eosinófilos e monócitos (THOMAS, 2002; MACHADO, 2004; KÜPPERS, 2009).

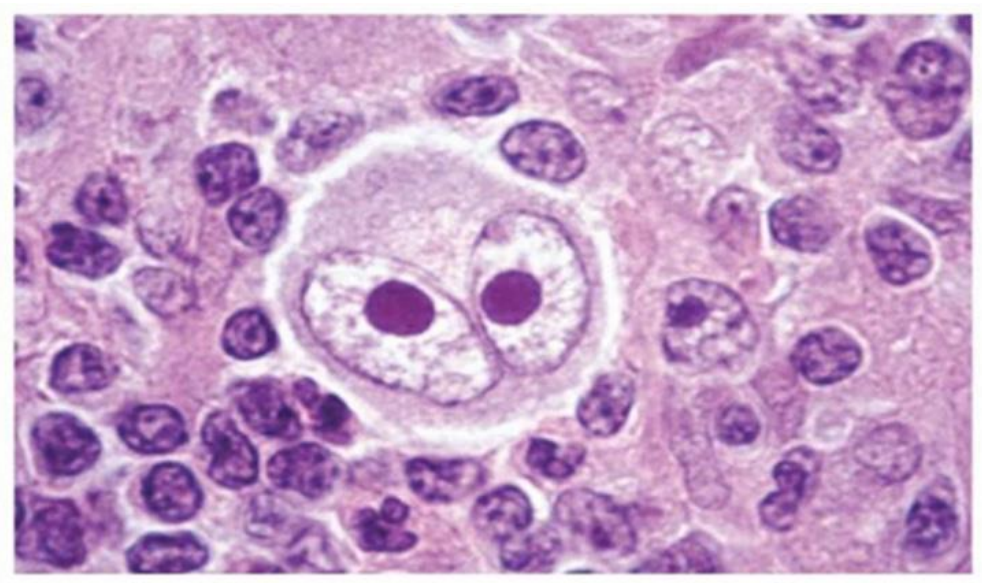

Figura 1 - Célula de Reed-Sternberg binucleada.

Fonte: telemedicina.med.muni.cz 
Durante muito tempo houve dúvidas em relação à origem das células de RS no LH (H-RS). No entanto, aparentemente, estas células originam-se de linfócitos $B$ no centro germinativo dos linfonodos e são células neoplásicas clonais. Possuem o formato característico de seu núcleo bilobado o que confere a essas células a aparência de olhos de coruja. Os nucléolos são eosinofílicos e bem aparentes. Pode também ser multinucleada ("moedas de pennies em um prato"). Normalmente, as células de RS são identificadas em cerca de $1 \%$ da área do tecido afetado, em raros casos podem ser observadas em até $10 \%$ do tecido. Tais células parecem derivar das células linfócitos $\mathrm{B}$ que foram expostas à antígenos ou sofreram mutação em alguma parte de seu processo maturacional. Esta baixa incidência de células características da doença de Hodgkin dificultam seu diagnóstico usando-se apenas técnicas de microscopia, por esta razão o diagnóstico passa por anamnese para se observar conjuntos de sintomas do tipo $A$ e do tipo $B$, dentre outros marcadores biológicos que possam expor a presença da malignidade (KÜPPERS 1993; KÜPPERS, 2005). Pessoas de todas as idades são acometidas por esse tipo de linfoma, que segue uma distribuição etária bifásica, cujo primeiro pico de incidência ocorre entre os 14 e 40 anos e o segundo pico, em adultos com mais de 50 anos, sendo mais comum em homens do que em mulheres (SMITH, 2005; RODAK, 2005). Atualmente, o LH é classificado em duas entidades distintas, o LH nodular com predominância linfocitária e o LH clássico; este último é subdividido em esclerose nodular rica em linfócitos, celularidade mista e depleção linfocitária (SWERDLLOW, 2008).

Há, também, a possibilidade de a doença ser causada por alguns agentes patogênicos como o vírus Epstein-Bar (VEB), um vírus da família da herpes, como relatado por diversos autores que sugerem a existência de uma associação entre o genoma do vírus e a doença de Hodgkin em, aproximadamente, $50 \%$ dos casos (WEISS, 1987; PALLESEN, 1991; KHAN, 1993), e uma explicação para tal se dá em razão do EBV estar localizado no interior das células de RS, no subtipo celularidade mista, e, ainda, sua presença no organismo pode ser considerado fator prognóstico independente para o LH clássico. Seu genoma é constituído de aproximadamente 100 genes que são expressos durante a replicação, mas somente 10 desses genes são expressos nas células B. A proteína viral LMP-1 é oncogênica e sua expressão resulta no aparecimento de linfomas de células $B$, visto que a diminuição das proteínas virais 
durante a latência do vírus diminui o número de proteínas que possam ser reconhecidas por células $T$ citotóxicas e permitem a evasão do vírus da destruição pelos mecanismos de defesa do sistema imune do indivíduo, além de ligar-se ao Fator de Necrose Tumoral, induzindo a proliferação e linfomas de células B (WEISS, 1987; GANDHI, 2004; PRATT, 2012; ELSAYED, 2014).

Para diagnosticar a doença, são considerados sinais e sintomas clínicos, seguidos por exames histológicos. Os sintomas do tipo A correspondem aos sintomas iniciais da doença e incluem o aumento indolor de um ou mais linfonodos e, geralmente, os da região cervical são os primeiros a ser afetados, que, em alguns casos, chegam a comprimir estruturas adjacentes, como esôfago ou brônquios, quando estão demasiadamente aumentados (GOLDMAN, 2005; SMITH, 2005; LOPES, 2006). Em mais de $80 \%$ dos casos, a linfadenopatia ocorre de maneira silenciosa, na região acima do diafragma, com envolvimento do mediastino anterior, podendo ser o único local de comprometimento, chegando, às vezes, a grandes volumes, antes mesmo dos pacientes apresentarem sintomas como tosse, sibilo e respiração curta (GOLDMAN, 2005). Somados aos sintomas do tipo A, há três sintomas específicos que constituem os da classe $B$ e que possuem correlação com o prognóstico do sobrevivente como febre $>38^{\circ} \mathrm{C}$ sem razão aparente, sudorese noturna excessiva e perda de mais de $10 \%$ do peso corporal, nos últimos seis meses, sem causa específica (ANSELL, 2012; METZGER, 2012). Alguns pacientes manifestam, ainda, sintomas como, prurido crônico, fadiga, dor e intolerância ao álcool (SCHMAIER, 2011).

Uma vez diagnosticado o linfoma de Hodgkin, são realizados exames para determinar o estágio da doença. Estudos laboratoriais e de imagens, além da biópsia da medula óssea, também fazem parte dos procedimentos recomendados para o estadiamento da doença (GOLDMAN, 2005), antes do início do tratamento. O tratamento e prognóstico para um paciente com linfoma de Hodgkin dependem tanto do tipo exato e da fase em que se encontra a enfermidade. Os exames usados para determinar o estadiamento incluem:

- Exame físico.

- Biópsias de gânglios linfáticos ou outras áreas anormais.

- Exames de sangue. 
- Exames de imagem.

- Aspiração de medula óssea e biópsia.

- Punção lombar.

Ao ser diagnosticado o LH, o seu estadiamento é classificado pelo sistema de Cotswold - mais utilizado para descrever a extensão do linfoma de Hodgkin, sendo este uma derivação do sistema Ann Arbor proposto em 1971 (CARBONE, 1971; SWERDLLOW, 2008). Neste sistema, os linfomas que afetam um órgão fora do sistema linfático (órgão extranodal) têm a letra $E$ adicionada ao seu estágio, (por exemplo, estágio IIE), enquanto aqueles que afetam o baço acrescentam a letra $\mathrm{S}$. Assim, o estadiamento do $\mathrm{LH}$, descrito abaixo e ilustrado na figura 2, é realizado após determinar os estágios clínico e patológico do paciente. Note-se que frequentemente os estágios I e II são considerados como estágios iniciais da doença e os estágios III e IV como avançados.

\section{Estágio I:}

- O linfoma está localizado em apenas uma área do linfonodo ou órgão linfoide, como o baço (I).

- O câncer é encontrado em apenas uma área de um único órgão fora do sistema linfático (IE).

\section{Estágio II:}

- O linfoma está localizado em 2 ou mais grupos de linfonodos do mesmo lado (acima ou abaixo) do diafragma, músculo que separa o tórax e do abdome (II).

- O linfoma se estende a partir de um único grupo de linfonodos para um órgão próximo (IIE).

\section{Estágio III:}

- O linfoma está localizado nas áreas dos nódulos linfáticos em ambos os lados (acima e abaixo) do diafragma.

- O câncer pode também ter se espalhado em uma área ou órgão ao lado dos gânglios linfáticos (IIIE), para o baço (IIIS), ou ambos (IIISE).

\section{Estágio IV}


- O linfoma se espalhou para fora do sistema linfático para um órgão que não está localizado próximo ao linfonodo.

- O linfoma se espalhou para órgãos em duas partes do corpo.

- O linfoma se espalhou para a medula óssea, fígado, cérebro ou pleura.

Outros modificadores que também podem ser utilizados para descrever o estágio do linfoma:

- Doença volumosa - Este termo é usado para descrever tumores localizados no tórax e que ocupam, pelo menos, um terço da largura da caixa torácica ou tumores localizados em outras áreas, com pelo menos $10 \mathrm{~cm}$ de diâmetro. Geralmente é adicionada a letra $X$ para designar este estágio.

- A x B - A cada estágio pode também ser atribuída a letra A ou B. A letra $B$ é adicionada (por exemplo, estágio IIIB) se uma pessoa tem algum dos sintomas $B$ : perda de mais de $10 \%$ do peso corporal nos últimos 6 meses (sem dieta), febre inexplicável e sudorese noturna.

Estes sintomas geralmente significam que a doença está mais avançada. Neste caso, um tratamento mais intensivo é recomendado. Se nenhum dos sintomas B estão presentes, a letra A é adicionada ao estágio.

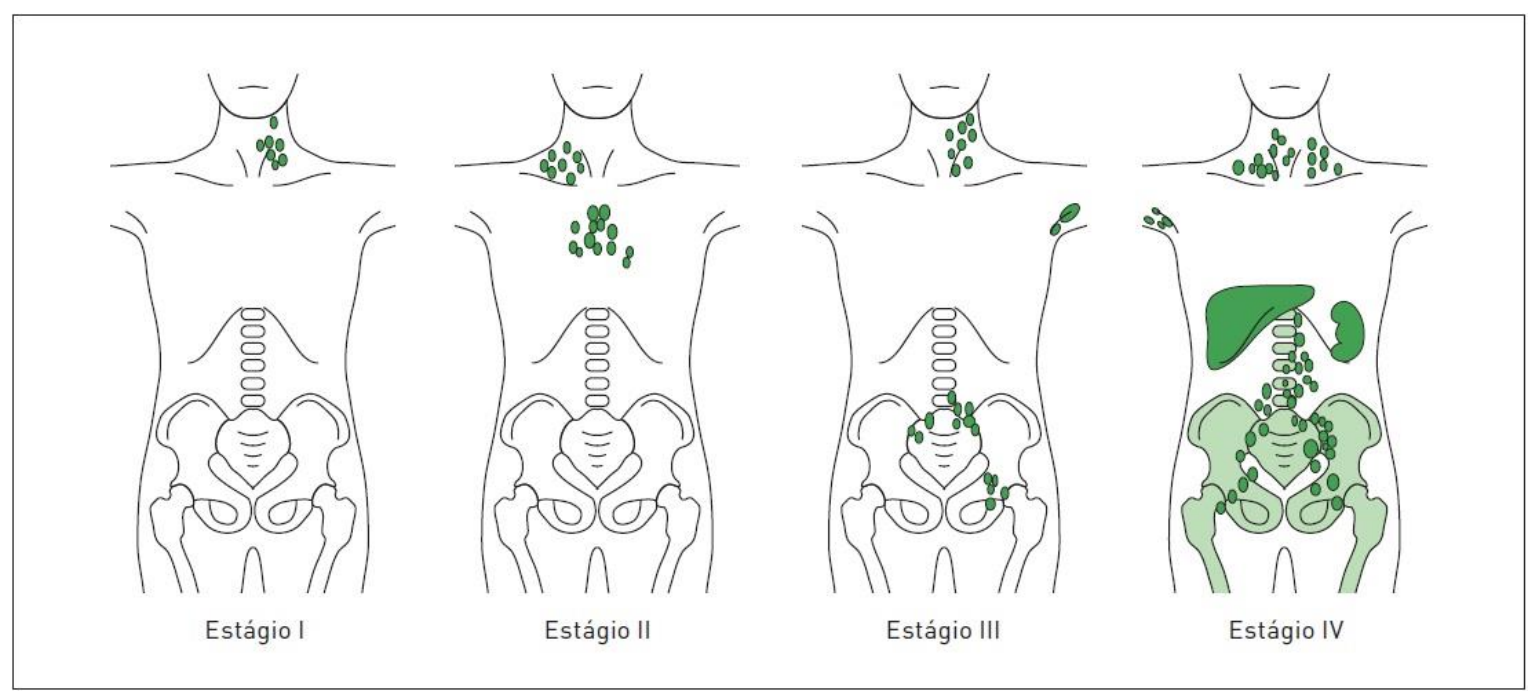

Figura 2: Regiões envolvidas no linfoma de Hodgkin de acordo com o Sistema de estadiamento de Ann Harbor. Fonte: Hoffbrand e Moss, 2013. 
Após a confirmação do diagnóstico desta condição, o indivíduo diagnosticado é encaminhado para tratamentos antineoplásicos. É preciso observar que é chamado de sobreviventes ao câncer todos aqueles indivíduos que receberam diagnóstico de câncer, independente do curso da doença, até o fim de sua vida. (RIES, L. A. G. et al, 2007).

\subsection{Tratamentos contra o LH}

A quimioterapia se consiste no uso de medicamentos que matam as células tumorais por interferir no processo de divisão celular. As células tumorais morrem devido à toxicidade dos quimioterápicos durante o seu processo de multiplicação. Ocorre que os quimioterápicos se espalham por todo o organismo pela corrente sanguínea, e não matam apenas células tumorais que estejam se dividindo, mas também células normais do organismo, que também se dividem. Devido a esse efeito sobre as células normais, que acabam morrendo também, é que os quimioterápicos têm diversos efeitos colaterais como queda de cabelo, mucosite, vômitos, diarreia, anemia, baixa da imunidade (baixa dos glóbulos brancos), risco de sangramento (baixa de plaquetas) entre outros (HOPPE, 2012; NCCN, 2015)

A quimioterapia pode ser empregada como tratamento isolado ou combinado com radioterapia dependendo do tipo do tumor, sua localização e o estágio da doença. As drogas quimioterápicas por serem sistêmicas, atuam nas células que se dividem rapidamente, por isso são utilizadas contra as células cancerosas. Porém, simultaneamente outras células no corpo, tais como as da medula óssea, o revestimento da boca e dos intestinos e os folículos pilosos, também se dividem rapidamente. Estas células são afetadas pela quimioterapia, levando a efeitos colaterais. Os efeitos colaterais da quimioterapia dependem do tipo e da dose das drogas administradas e do período de tempo do tratamento. Os medicamentos podem, também, ser tóxicos para os ovários e as células germinativas, podendo, em alguns casos, levar à esterilidade ou à menopausa precoce induzida. Os medicamentos quimioterápicos estão divididos em várias classes, com base no mecanismo pelo qual interferem na divisão celular. Quimioterápicos de diferentes classes podem ser combinados para ter maior eficácia contra o câncer, mas com 
consequente maior toxicidade. Quando se trata de aplicar quimioterapia com intuito curativo, é frequente a combinação de diversos quimioterápicos, e aceitável um grau maior de toxicidade. Para o LH, atualmente, o protocolo quimioterápico ABVD é o mais usado para tratamento da doença. A abreviatura representa quatro drogas: adriamicina (Doxorrubicina), bleomicina, vimblastina e dacarbazina. Desenvolvido na Itália na década de 1970, o tratamento ABVD normalmente leva entre seis e oito meses, embora tratamentos mais longos possam ser necessários (DOMINGUEZ, 2004; NCCN 2016). O tratamento com protocolo ABVD têm se mostrado eficiente no combate à doença, porém, apesar de avanços médicos e farmacológicos, ainda há relatos de efeitos colaterais pontuais e tardios relacionados a esse tratamento (GOTTI, 2013).

Enquanto a quimioterapia possui ação sistêmica, a radioterapia é um tratamento loco regional indolor no qual se utiliza radiação ionizante (processo de produção química com espécies eletricamente carregadas, pela perda ou ganho de elétrons, atuando sobre moléculas neutras ou átomos) para destruir, eliminar ou impedir que as células de um tumor aumentem seu tamanho, existem vários tipos de radiação, porém as mais utilizadas são as eletromagnéticas (Raios X ou Raios gama) e os elétrons (disponíveis em aceleradores lineares de alta energia). Comumente, a radioterapia é ministrada após o tratamento quimioterápico. Portanto, é possível que durante o tratamento radioterápico, a paciente ainda perceba sintomas e efeitos colaterais (nos aspectos psicológicos/cognitivos e físicos) da quimioterapia, visto que os efeitos tardios da mesma podem durar ainda cerca de um ano ou mais após o fim do tratamento, porém, devido ao quadro específico e ao tipo de tumor de cada paciente, existem diversas formas de utilização da Radioterapia. O efeito colateral mais comum é a queimadura da pele na área irradiada, semelhante a uma queimadura solar importante. Outros efeitos colaterais são fadiga, desconforto na axila, raramente dor torácica ou problemas cardíacos (raríssimo, com equipamentos modernos), queda temporária na produção de sangue (anemia, baixa de glóbulos brancos e de plaquetas). O LH pode ser subdividido em dois grupos: favoráveis e desfavoráveis ao tratamento, de acordo como prognóstico; o primeiro apresenta melhores resultados na terapia combinada (quimioterapia -QT- e radioterapia - RT) quando comparados ao segundo. Neste, usar campos menores de irradiação (a tendência atual para radioterapia) não tem diferença na sobrevida. No grupo de favoráveis no estádio 
inicial, doses menores de QT e RT são eficazes. Nos estágios III e IV em geral, a adição de RT apenas aumenta o tempo livre de doença, mas não a sobrevida (MARTA, 2012).

Independentemente do tipo de câncer diagnosticado, é comum o predomínio de sintomas como dor, náusea, vômitos e fadiga, em pacientes tratados com QT (SEIXAS, 2010). Naqueles com câncer hematológico, os sintomas mais frequentes foram náusea, vômito, insônia, fraqueza, dor ou desconforto, prejuízo na função cognitiva e emocional (ANDRADE et al. 2013).

Ambas as terapias possuem certa toxicidade e podem causar desordens e efeitos colaterais pontuais e tardios, podendo estes efeitos perdurarem por anos, mesmo findo o tratamento. Tais efeitos, comumente relatados pela literatura, podem ser de caráter físico como desordens dos sistemas cardiovascular, pulmonar, imunológico, endócrino, perda de massa magra e perda de força e funcionalidade, aumento da incidência de sobrepeso e obesidade, diminuição da densidade mineral óssea (DMO), fadiga, e neuropatia periférica; além de fatores psicológicos como déficit cognitivo, distresse psicológico, ansiedade, depressão e problemas psicossociais (DEMARK-WAHNEFRIED et al., 2002; ADAMS e LIPSHULTZ, 2007; MAKARI-JUDSON et al, 2007; CHEN et al., 2010; THIVAT et al., 2010; YAW et al., 2010; THIBAULT et al., 2012).

\subsection{Composição Corporal}

A composição corporal é uma variável que pode sofrer influência tanto da própria condição crônica quanto das terapias antineoplásicas (YAW et al.,2010; EWERTZ et al., 2011). Além disso, um balanço energético inadequado, alterações hormonais, as atividades laborais, o nível de independência e de atividade física podem ser aspectos alterados com o tratamento do câncer e que pode refletir diretamente na massa corporal, independência física e possivelmente em um pior prognóstico, e pobre qualidade de vida em sobreviventes de câncer (FOULADIUN et al., 2005; GADÉA et al., 2011; PAXTON et al., 2012). É comum observar que sobreviventes de câncer sofrem alterações não favoráveis na composição corporal, 
como perda de massa magra, aumento de massa gorda e diminuição da DMO. Porém, esse mecanismo de perda de massa magra, ganho de massa gorda e aumento do percentual de gordura e índice de massa corporal ainda não é bem compreendido pela ciência (VISOVSKY, 2006).

Apesar das medidas objetivas parecerem unânimes no que diz respeito ao risco de extremos da massa corporal para a saúde de sobreviventes, não estão claros quais os reflexos das alterações da massa corporal nas avaliações subjetivas de saúde. Há indícios de que o aumento da massa corporal pode estar associado, também, a uma qualidade de vida reduzida em sobreviventes ao câncer (PAXTON et al., 2012), não estando ainda claros quais aspectos do sobrepeso e da obesidade estariam associados a esta redução.

Ainda, o fator da alteração da composição corporal é considerado uma fonte de distresse psicológico durante e após o tratamento, além de aumentar chances de desenvolvimento de comorbidades e outras condições crônicas, como doenças cardiovasculares, diabetes, hipertensão e problemas articulares (HEYLER et al., 2010). Por fim, a elevação do índice de massa corporal (IMC) está associada não somente ao risco de diversas formas de câncer, como também, a mortalidade prematura naqueles acometidos por esta condição (REEVES et al., 2007; CHEN et al., 2010; PARR et al., 2010). Dados da população norte-americana indicaram que os padrões de obesidade no ano de 2003 seriam responsáveis por $14 \%$ a $20 \%$ de toda a mortalidade por câncer naquele país (CALLE et al., 2003). Segundo uma revisão sistemática de evidência realizada pela World Cancer Research Fund e pelo Instituto para Pesquisa em Câncer (AICR) (MARMOT, 2007), foi concluído que a gordura corporal tem um risco estabelecido para o desenvolvimento de diversos tipos de câncer e se mostrou associada ao aumento da mortalidade de câncer (CALLE et al, 2003) e baixa qualidade de vida, o que inclui déficits na funcionalidade física e uma pior resposta ao tratamento contra o câncer (MOSHER et al, 2009); tal conclusão corrobora com Siegel et al (2011) que estimou que mais de 50\% dos casos de diversos os tipos de câncer foram detectados em locais onde havia a implicação de obesidade.

Existem diversos mecanismos que potencialmente ligam a adiposidade corporal ao surgimento do câncer, sua progressão e mortalidade. Mesmo que não sejam totalmente esclarecidos, sabe-se que esses mecanismos têm papel 
fundamental tanto na progressão da doença quanto na resposta do organismo ao tratamento.

\subsection{Força muscular em sobreviventes de LH}

O tratamento antineoplásico é extremamente agressivo, tanto para as células cancerosas, quando para tecidos saudáveis. Dentre os tecidos e sistemas que sofrem com a toxicidade do tratamento, o tecido muscular é extremamente prejudicado em indivíduos com câncer - tanto por conta da própria doença quanto pelo tratamento prescrito. Uma das condições mais comuns e recorrentes que acomete sobreviventes é a caquexia, constituída por uma condição altamente debilitante acarretada por acentuada perda de peso, de massa magra, diminuição de força e potência muscular, anemia, resistência à insulina e fadiga (que é causada, também, por outros fatores). A caquexia afeta indivíduos com certas doenças crônicas como câncer, síndrome da imunodeficiência adquirida (SIDA), insuficiência cardíaca, dentre outras, e, ainda, é uma condição que comumente afeta idosos (WOLFE, 2006; ACHARYYA, 2007). Tal condição mostra-se mais presente em cânceres de pulmão, gastrointestinais e de mama, porém, ainda que em menor proporção, pode estar presente em pacientes com cânceres hematológicos, como o LH e, além dos problemas de mobilidade e fadiga, a caquexia também influencia na resposta (pontual e tardia) do indivíduo aos tratamentos quimio e radioterápicos (MORLEY, 2006; ACHARYYA, 2007; EVANS, 2008).

Além disso, a caquexia contribui para o declínio da qualidade de vida do sobrevivente e é altamente preditora do aumento de mortalidade, sua etiologia é multifatorial e multidimensional e não é apenas sinônimo de perda de peso. A condição envolve questões nutricionais, como anorexia, diminuição da absorção de nutrientes, anemia, além de um, estado de inflamação sistêmica, com a presença de citocinas inflamatórias, alterações da função mitocondrial, aumento de produção de espécies reativas de oxigênio e diminuição da produção de hormônios anabólicos. (FEARON, 2006; MORLEY, 2006; EVANS, 2008). Os níveis de mortalidade em câncer parecem estar diretamente relacionados à composição corporal e suas alterações decorrentes da doença e do tratamento. Obesidade e caquexia contribuem para um pior 
prognóstico, uma menor taxa de sobrevivência e uma pior qualidade de vida do indivíduo. Apesar dos mecanismos de ação dos componentes da composição corporal ainda serem incertos.

Há evidências mostrando que questões nutricionais influenciam no quadro de caquexia, porém, quando esta questão é tratada, o quadro ainda se mostra presente. As teorias envolvendo estado inflamatório sistêmico e disfunções metabólicas parecem auxiliar e complementar as possíveis causas e sequelas desta síndrome.

Neste sentido, medidas de composição corporal e de força podem trazer ao sobrevivente informações importantes sobre estas variáveis componentes de sua condição de saúde. Dentre as diferentes medidas de força existentes, o pico de torque absoluto e o pico de torque relativo obtidos através de dinamômetro isocinético, se mostram fidedignas e confiáveis para o propósito deste estudo (DROUIN, 2004). Portanto, o pico de torque absoluto representa o ponto de maior torque na amplitude do movimento, é o resultado da força aplicada em um ponto multiplicada pela distância do ponto de aplicação desta força ao centro de rotação do eixo de movimento - o que pode ser traduzido pela equação $T=F . d$, sendo sua unidade de medida Newton vezes metro (Nm) (TERRERI, 2001), enquanto o pico de torque relativo é a medida do pico de torque absoluto relativizado pela massa corporal do indivíduo.

\subsection{Fadiga Relacionada ao Câncer}

A FRC é um sintoma persistente, distressante e um dos mais debilitantes dentre o conjunto de sintomas que acompanham o tratamento e a sobrevida de indivíduos com câncer, é clinicamente descrita como cansaço descomunal, exaustão, falta de energia e esgotamento e, diferente de uma fadiga não relacionada ao câncer, este sintoma é persistente e parece não melhorar com descanso ou horas adequadas de sono. Cerca de $70 \%$ dos sobreviventes de câncer apresentam este sintoma e o declaram como fonte de distresse e desânimo na sua qualidade de vida relacionada à saúde e na execução de suas atividades da vida diária. Sabe-se que os sobreviventes de LH são, de forma geral, mais fadigados que a população geral, por isso atualmente a FRC é tratada como fator primordial na busca da promoção de 
saúde de sobreviventes com câncer, visto que, nos últimos 40 anos houve avanços importantes na investigação da FRC, nos instrumentos capazes de analisar este sintoma e nos cuidados e atitudes acerca do tratamento deste quadro (LOGE, 1998; DIMEO 2001; BRYANT, 2015).

Por ser algo tão complexo, com tantas vertentes tentando explicar sua origem, causa e sugerir sua solução, existem diversas formas de procurar compreender os aspectos da FRC, tal como mostra a figura, adaptada, a seguir:

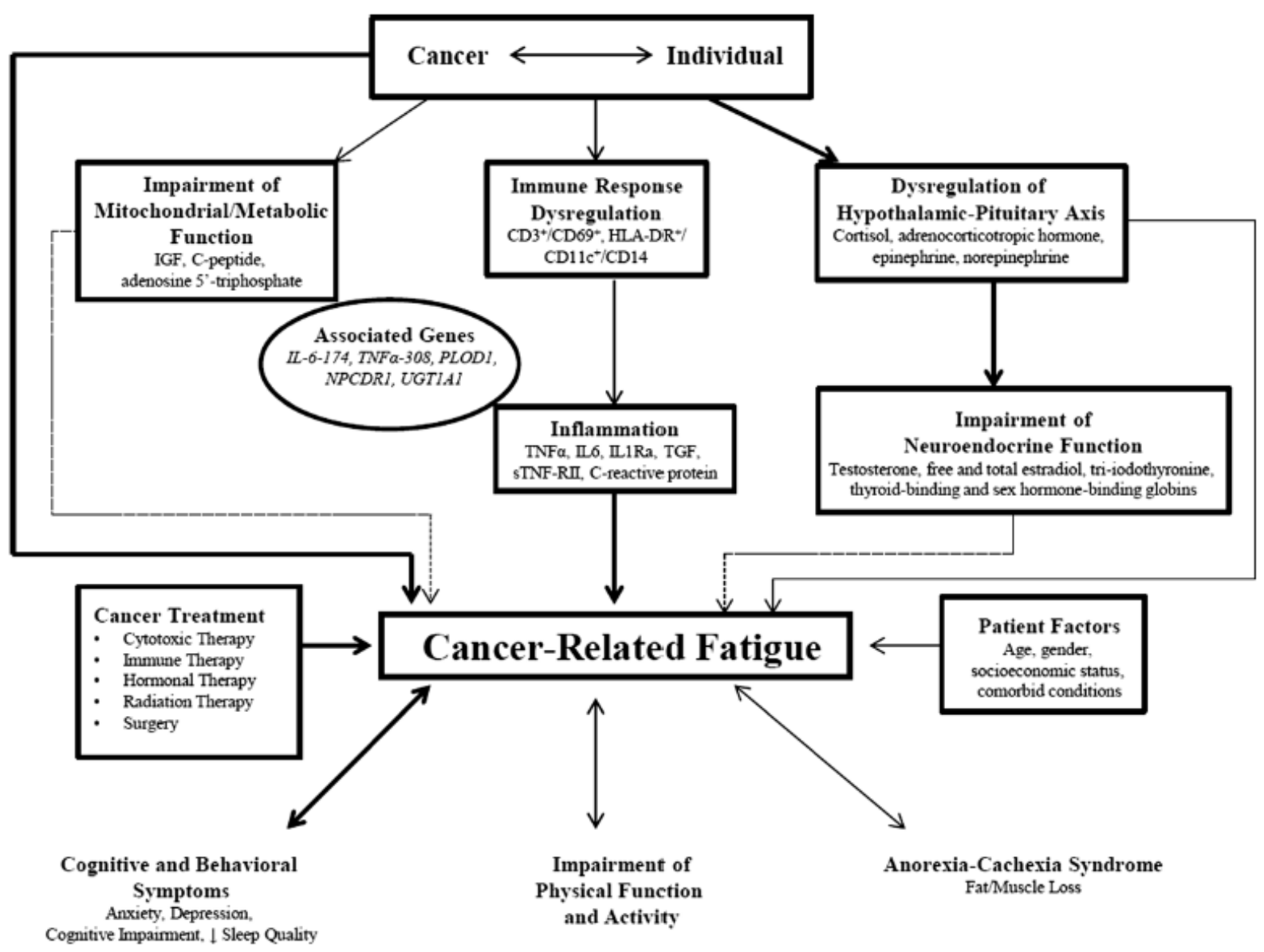

Figura 3: extraída na íntegra de Saligan (2015).

A FRC ainda tem sua etiologia incerta, visto que estudos que buscaram investigá-la o fizeram a partir da análise de diversas variáveis tanto físicas quanto psicológicas, objetivas e subjetivas, mas ainda restando dúvidas quanto à sua causa e origem. Há pesquisas indicando que a FRC seja de origem central, ou seja, o sistema nervoso central (SNC) estaria, de alguma forma, alterado e as disfunções causadas tanto pelo processo da doença quanto pelo tratamento seriam capazes de 
afetar diversos domínios tanto fisiológicos quanto psicológicos do sobrevivente (LUCIA, 2003).

Acredita-se que a FRC possa estar ligada, também, a disfunções fisiológicas como aumento sistêmico de fatores inflamatórios, alterações endócrinas como níveis de alguns neurotransmissores (serotonina e dopamina), alterações da microbiota intestinal, alterações da função mitocondrial, aumento de stress oxidativo, disfunções do eixo hipotalâmico-pituitário-adrenal, disfunção da ressíntese de ATP muscular (STACKHOUSE et al., 2001; FINSTERER, 2012; SIEGLER et al., 2015).

Há, também, pesquisas que buscam analisar os domínios subjetivos para explicar a FRC, como a presença de depressão, distresse psicológico, ansiedade, dentre outros sintomas relatados como relata, Okuyama (2000) que corrobora com Bower (2000) ao relatar que encontrou correlação significativa entre depressão e todas as dimensões de fadiga e afirmar que a fadiga para esta população parece estar mais relacionada ao distresse físico e psicológico que à doença em si e seus tratamentos. E, ainda, em seu estudo, Winters-Stone (2001) defende que a FRC pode estar associada ao estado de estresse, pois encontrou associação significativa entre severidade da fadiga e estresse psicológico, náusea, dor, dispneia dentre outros sintomas de efeitos colaterais do tratamento radioterápico, mas a maior associação foi entre a severidade da fadiga e depressão. De forma geral, pesquisadores analisam a FRC como variável dependente de sintomas como ansiedade e depressão (CULL, 1996; HOGE, 2000).

De forma geral, sobreviventes de LH tendem a apresentar maiores níveis de fadiga que sujeitos aparentemente saudáveis e isso estaria relacionado à diversos fatores clínicos que acompanham o sobrevivente desde o seu diagnóstico até muitos anos de sobrevida (FOBAIR, 1986; LOGE, 1998; RUFFER, 2003).

\subsection{Distresse psicológico}

O diagnóstico do câncer, assim como o período de sua terapêutica, traz ao sobrevivente um conjunto de sintomas, sentimentos e sensações negativas e angustiantes. Os sobreviventes comumente relatam dificuldades em retomar sua vida 
e suas atividades diárias da mesma forma que faziam antes do diagnóstico, alterações no sono, dificuldades com a alimentação e sintomas físicos que, somados à desajustes psicossociais sofridos no tratamento trazem sentimentos estressantes como medo de recorrência da doença, ansiedade e depressão (BAUM, 1982; CELLA, 1986; FOBAIR, 1986). Diante disso, se fazem necessárias avaliações psicológicas específicas para pacientes oncológicos e, ainda, para seus familiares, a fim de promover cuidados específicos aos sobreviventes de longo prazo e promover-lhes qualidade de vida por meio de suporte profissional e qualificado (HOFFMAN, 2009).

O distresse psicológico é apenas uma manifestação de resultados de análises psicossociais em sobreviventes de câncer, que pode estar associado a questões físicas, fisiológicas, psicológicas e sócio afetivas, podendo ser considerado de caráter positivo - quando envolve crescimento pessoal, superação e resiliência ou de caráter negativo - quando envolve depressão ansiedade ou diminuição da qualidade de vida. Quando se fala sobre o distresse enfrentado pelo sobrevivente, é preciso evidenciar que ele se trata e é causado a partir de um conjunto de sintomas e emoções, que vão desde autoimagem e autoestima à suporte social e familiar. O baixo suporte social e familiar, assim como alterações bruscas da composição corporal tendem a trazer altos níveis de distresse percebido (MORASSO, 2010). Essas alterações provocam reações fisiológicas como distúrbios do sono, aumento da fadiga, alterações na produção de serotonina, alterações da microbiota intestinal, aumento da secreção de cortisol e, ainda, dificultam a aderência do paciente ao tratamento multidisciplinar - não apenas o tratamento quimioterápico, por exemplo. E, para haver investigação e manejo destes sintomas é preciso contar com ferramentas precisas e eficazes para, a partir disto haver a promoção de saúde do sobrevivente (PACHMAN, 2012).

Neste sentido, o termo distresse foi adotado pela National Comprehensive Cancer Network (2007) como forma de se referir especificamente ao estresse vivenciado pelo paciente oncológico desde a fase de diagnóstico. Distresse é definido como uma experiência emocional desagradável e multifatorial, de natureza psicológica, social e/ou espiritual, que oscila entre a percepção da própria vulnerabilidade, tristeza, fantasias e medo ante o desconhecido e reações mais intensas como depressão, ansiedade, pânico, crises existenciais e isolamento social. Portanto, é considerado como uma resposta natural de uma pessoa que vivencia a 
doença e seu tratamento, caracterizando-se, por exemplo, por uma variação constante de humor. Mas, também abrange evoluções mais graves, que podem conduzir a um distúrbio psiquiátrico, tais como depressão maior ou distúrbio de ansiedade generalizada (NATIONAL COMPREHENSIVE CANCER NETWORK, 2007; DECAT, 2011). Desta forma, existem diversas ferramentas que visam identificar sintomas que estejam ligados ao distresse, alguns desses instrumentos avaliam sintomas específicos, como depressão, ansiedade, fadiga e estados de humor, enquanto outros buscam, de maneira mais abrangente, avaliar a qualidade de vida relacionada à saúde do sobrevivente (BOTEGA, 1995; CARLSON E BULTZ, 2003; DECAT, 2009). Segundo Bultz (2005), o distresse emocional deveria ser considerado um sexto sinal vital do paciente e deveria ser monitorado rotineiramente assim como demais sinais e sintomas que cercam o sobrevivente, visto que o manejo da condição emocional e psicológica do sobrevivente, tirando-Ihe esta condição de fardo, pode colaborar com sua melhora psicológica e física.

Sob a necessidade de um instrumento de rápida e fácil aplicação e de boa usabilidade e confiabilidade, em 1997, a National Comprehensive Cancer Network (NCCN) e a American Society of Clinical Oncology (ASCO) propõem um protocolo para diagnosticar e tratar o distress, denominado "Distress Management" (NATIONAL COMPREHENSIVE CANCER NETWORK, 2007). Em linhas gerais, trata-se de um manual, elaborado por profissionais de diversas áreas relacionadas ao cuidado em oncologia, que estabelece objetivamente o quadro sintomático e sugere métodos de intervenção e acompanhamento (CARLSON \& BULTZ, 2003; CARLSON et al, 2004). $O$ instrumento foi intitulado de Termômetro de Distresse (TD) e, para o idioma português, foi validado por Decat (2009), que evidencia sua viabilidade como instrumento de medida para o contexto brasileiro e sua e exalta relevância na identificação dos momentos cruciais de intervenção psicológica durante o acompanhamento terapêutico TD mostra-se como ferramenta breve e simples, tanto para aplicação quanto para interpretação pela equipe multidisciplinar envolvida com o sobrevivente. Este instrumento, de acordo com suas diretrizes, considera que uma pontuação $\geq 4$ indica distresse moderado a severo e requer observação e futura avaliação, enquanto uma pontuação <4 significa baixo nível de distresse ou distresse esperado (NATIONAL COMPREHENSIVE CANCER NETWORK, 2003). 


\section{MATERIAIS E MÉTODOS:}

O presente estudo se caracteriza como transversal correlacional.

\subsection{Local da realização do estudo}

Todas as avaliações foram realizadas na Faculdade de Educação Física (FEF) da Universidade de Brasília (UnB), nos laboratórios de treinamento de força e de imagem.

\subsection{Amostra:}

1. Participaram como voluntários deste estudo doze sobreviventes de $\mathrm{LH}$, designados como grupo linfoma (GL), domiciliados no Distrito Federal (DF), com idade entre 18 e 60 anos.

Para o GL os critérios de inclusão para a participação no estudo foram:

a. Estar inserido na faixa etária de 18-60 anos;

b. Ter sido diagnosticado com LH nos estadiamento entre I e III;

c. Ter concluído o tratamento prescrito há pelo menos seis meses;

d. Concordar em realizar o exame de composição corporal, bem como o teste físico, e responder aos questionários;

e. Assinar o Termo de Consentimento Livre e Esclarecido (TCLE).

O critério de exclusão foi:

a. Possuir doença cardíaca, hipertensão sem controle, doença respiratória crônica ou aguda, diabetes mellitus não controlado, doença mental, imunidade não controlada, infecção, comprometimento musculoesquelético severo, marca-passo, amputação de membros;

2. Participaram, também, como voluntários deste estudo 79 indivíduos aparentemente saudáveis, pareados por idade com os sobreviventes do estudo, designados como grupo controle (GC), domiciliados no Distrito Federal (DF), com idade entre 18 e 60 anos. 
Para o GC os critérios de inclusão para a participação no estudo foram:

a. Estar inserido na faixa etária de 18-60 anos;

b. Ser aparentemente saudável;

c. Concordar em realizar o exame de composição corporal, bem como o teste físico, e responder aos questionários;

d. Assinar o Termo de Consentimento Livre e Esclarecido (TCLE).

Os critérios de exclusão foram:

Possuir doença cardíaca, hipertensão sem controle, doença respiratória crônica ou aguda, diabetes mellitus não controlado, doença mental, imunidade não controlada, infecção, comprometimento musculoesquelético severo, marca-passo, amputação de membros.

\subsection{Procedimentos da coleta de dados}

Os voluntários compareceram a Faculdade de Educação Física (FEF) da Universidade de Brasília (UnB) apenas uma vez, por um período de aproximadamente duas horas. Inicialmente foram explicados os procedimentos e sugerida a assinatura do TCLE. Em sequência, os voluntários responderam a questionários de anamnese e avaliação sociodemográfica, além de uma análise da fadiga auto percebida, por meio do Inventário Multidimensional de Fadiga (IMF-20) (SMETS, 1995; BAPTISTA 2012). Após o preenchimento dos questionários e a avaliação da fadiga, os voluntários foram submetidos a avaliação antropométrica e de composição corporal. Posteriormente, realizou-se a avaliação do pico de torque isocinético em uma velocidade de 60 o.s-1.

Com o objetivo de padronizar as avaliações, o membro direito foi utilizado na avaliação do pico de torque isocinético. A ordem das avaliações foi mantida de forma rigorosa, a fim de evitar qualquer influência de alterações morfológicas ou psicológicas promovidas pelo protocolo de avaliação da força na medida de composição corporal, qualidade muscular e fadiga. Nesse sentido, os voluntários foram orientados a não realizar atividades físicas vigorosas 48 horas antes dos procedimentos experimentais. 


\subsection{Instrumentos de avaliação:}

Questionário demográfico, sociocultural e biomédico (Apêndice A): Os dados foram coletados por meio de questionário, cujo objetivo é caracterizar a amostra, com dados referentes ao gênero, idade, estado civil, grau de instrução, renda, tipo de ocupação, religião, renda familiar, composição familiar, hábitos de vida (tabagismo, etilismo), estado menopausal dentre outros dados de caracterização.

Questionário anamnese (Apêndice B): Os dados foram coletados por um questionário, cujo objetivo é recolher dados dos sobreviventes relacionados à aspectos específicos da doença, data dos diagnósticos, número de sessões de tratamentos, sinais e sintomas experienciados dentre outros.

Dados antropométricos e composição corporal: A massa corporal foi mensurada utilizando uma balança digital da marca Ramuza, modelo ISR 10.000, com capacidade máxima de $200 \mathrm{~kg}$ e resolução de $50 \mathrm{~g}$. Para a medida das circunferências (perimetria), será utilizada a trena antropométrica Sanny Medical SN-4010, sem trava, com 2 metros de comprimento, com divisão da escala em milímetros, fabricada em aço carbono, corpo em ABS, flexível e inelástica.

Para a medida da estatura foi utilizado um dispositivo eletrônico que acompanha a balança Wiso ${ }^{\circledR}$, modelo $\mathrm{W}-721$, no qual um sensor infravermelho é colocado no vertex da cabeça do indivíduo e acionado, emitindo um feixe de raios que é recebido por outro dispositivo localizado na base na balança, onde o valor da estatura é resultado da distância entre o sensor localizado na superfície frontal da balança e o dispositivo posicionado sobre o ápice da cabeça do indivíduo. Esta distância é obtida por um método de ultrassom e raios infravermelhos. Os dados obtidos nestas medidas serão utilizados para calcular o Índice de Massa Corporal (IMC), calculado através da fórmula definida por Quetelet, onde a massa corporal é dividida pelo quadrado da estatura, e a classificação dos resultados será de acordo com a WHO (2000). 
A composição corporal foi mensurada através da Absortometria com Raios$X$ de Dupla Energia (DEXA), utilizando o densitômetro ósseo da marca General Eletric GE Healthcare ${ }^{\circledR}$, modelo Lunar Prodygy Pro ${ }^{\mathrm{TM}}$ (GE Lunar, Madison, WI). Os dados serão analisados por meio do software GE Medical Systems Lunar ${ }^{\mathrm{TM}}$. No presente estudo será mensurada o percentual total da gordura corporal, o percentual da massa livre de gordura total, a massa de gordura e massa livre de gordura. O Índice de Massa Corporal foi mensurado usando-se a fórmula: \% de gordura = (circunferência do quadril/altura x (Valtura))-18.

Fadiga (Anexo I): A fadiga foi avaliada pelo Inventário Multidimensional de Fadiga (IFM-20). Trata-se de um questionário auto administrado que contém 20 itens, dispostos em cinco escalas, relacionadas a diferentes dimensões da fadiga, sendo 1) geral, 2) física, 3) mental, 4) redução da atividade e 5) redução da motivação sobre a construção de fadiga (Anexo 1). Cada escala é composta por quatro itens, dois indicativos e dois contra indicativos de fadiga, e as afirmações referem-se a aspectos da fadiga experimentados durante os dias anteriores. Todos os itens são respondidos em uma escala fivepoint (1 1/4 "Sim, é verdade" e 5 1/4 "Não, não é verdade"). A pontuação é calculada para cada escala, variando de quatro a 20 pontos e quanto maior o escore, maior grau de fadiga. A versão em língua portuguesa foi validada por Baptista (2012), em uma população com LH. No artigo original, o autor não recomenda o uso de uma pontuação total, obtida a partir da soma das cinco escalas. Caso haja interesse em apenas uma pontuação como indicador de fadiga, recomenda-se utilizar a pontuação da escala de fadiga geral. Além disso, não há ponto de corte definido pelo autor, no artigo original (SMETS, 1995).

Termômetro de distress (Anexo II): A ferramenta para avaliação de distress psicológico - denominada Distress Thermometer - utilizada por este estudo é simples e de fácil análise. Tem o objetivo de identificar o nível de distress e suas possíveis causas no período referente à semana anterior, incluindo o dia em que essa avaliação está acontecendo. Ela é composta por dois instrumentos, um que analisa o nível de distress e outro que identifica suas possíveis causas (Lista de Problemas) (NATIONAL COMPREHENSIVE CANCER NETWORK, 2007). O primeiro é apresentado como um termômetro e permite que o paciente assinale o nível de distress, partindo do 0 (zero) - sem distress - até 10 (dez) - distress extremo. O indivíduo é considerado em 
situação de distress quando marca uma pontuação igual ou superior a 4. Já a Lista de Problemas que compõe o instrumento contém 35 itens voltados para o reconhecimento de possíveis causas do distress, mesmo que estas não estejam associadas ao diagnóstico ou ao tratamento. A simplicidade e eficácia do Termômetro de Distress, que pode ser aplicado por qualquer profissional de saúde, tornam possível a sua inclusão na rotina de atendimento em oncologia, o que favorece o diagnóstico precoce de possíveis transtornos de humor e de ajustamento, alguns bastante limitantes no enfrentamento da doença e na adesão ao tratamento (DECAT, 2009).

Avaliação isocinética: A força isocinética foi mensurada pelo pico de torque isocinético (PT) obtido em um dinamômetro isocinético Biodex System 3 (Biodex Medical, Inc., Shirley NY, USA). O equipamento foi calibrado de acordo com as recomendações do fabricante. Os voluntários foram posicionados confortavelmente no assento do dinamômetro e fixados por cintos de segurança no tronco, pélvis e coxa, com o objetivo de minimizar qualquer movimento corporal que alterasse os ângulos de ação e influenciassem o pico de torque. Todos os indivíduos foram orientados a segurar com os braços cruzados nos cintos de estabilização do tronco. O epicôndilo lateral do fêmur foi utilizado como ponto de referência e alinhado com o eixo de rotação do dinamômetro. A amplitude de movimento da extensão e flexão do joelho foi determinada em 850 . A correção da força da gravidade exercida no braço de força do dinamômetro foi realizada pela mensuração da força exercida pelo próprio braço e pela perna do indivíduo avaliado. Essa mensuração foi realizada sempre a 300 de extensão, como forma de padronização. Todas as análises e correções foram realizadas com o software Biodex Advantage (Biodex Medical, Inc., Shirley NY, USA).

Como familiarização e aquecimento, os voluntários realizaram uma série de 10 repetições de extensão isocinética unilateral de joelho a 1200.s-1. Após a familiarização/aquecimento, os voluntários permaneceram em repouso durante 5 minutos, antes da realização do protocolo de análise de força. O pico de torque foi mensurado por meio de um protocolo composto por duas séries de quatro repetições a 60o.s-1 (BOTTARO, 2005). O intervalo entre as duas séries do protocolo de análise da força foi de três minutos, posto que recentes estudos sugerem que sobreviventes de câncer necessitam de um intervalo de recuperação entre séries de exercício resistido superior para a manutenção da força e do trabalho, quando comparados com 
indivíduos saudáveis (VALERIANO, 2015; VIEIRA, 2015). Nesse sentido, uma recente pesquisa do Grupo de Pesquisa em Exercício e Câncer da UnB, realizada por Valeriano et al. (2015), com sobreviventes de LH sugere que três minutos seja o intervalo ideal entre séries de 10 repetições de extensão isocinética unilateral de joelho para manutenção do trabalho. De forma análoga, buscamos evitar qualquer efeito residual na segunda série do teste que pudesse impedir a realização da força máxima. Durante o exercício, os voluntários receberam incentivo verbal padronizado do pesquisador. Todas as avaliações foram realizadas pelo mesmo avaliador.

A partir dos resultados da avaliação isocinética das duas séries realizadas pelos indivíduos, foi extraído o maior valor de cada variável de medida de força: o pico de torque absoluto (PT) e o pico de torque relativo (PTR), normalizado pelo peso corporal do indivíduo. Dessa forma, espera-se minimizar os efeitos da heterogeneidade da amostra e da presença de voluntários de ambos os sexos na presente pesquisa.

\subsection{Tratamento estatístico}

Os dados foram analisados utilizando o software SPSS versão 21 (SPSS Inc., Chicago, IL, EUA).

Para verificar a normalidade da amostra utilizou-se o teste de Shapiro-Wilk para o grupo LH e o teste de Kolmogorov-Smirnov para o grupo controle.

Média e desvio padrão das variáveis foram feitas por estatística descritiva, enquanto a comparação das variáveis entre os dois grupos foi feita através do teste T de student para amostras independentes - que apresentaram normalidade - e teste Wilcoxon-Mann-Whitney para amostras que não apresentarem distribuição normal. Sendo assim, para as variáveis que apresentaram normalidade, a correlação foi feita a partir do teste de Pearson ( $r$ ), enquanto as variáveis não-paramétricas foram correlacionadas através do teste de Spearman. A classificação de força da correlação de Pearson foi feita de acordo com DANCEY E REIDY (2005). O cálculo do tamanho do efeito das estatísticas descritivas foi obtido por meio do teste de Cohen (d) (COHEN, 1992) cuja classificação é: tamanho do efeito pequeno para valor de d entre 
0,20 e 0,30; médio para valor de d entre 0,40 e 0,70 e grande para valor de $d \geq 0,80$. Ademais, o nível de significância estatística adotado foi de $p \leq 0,05$.

\subsection{Aspectos éticos}

Esta pesquisa foi aprovada pelo Comitê de Ética em Pesquisa com Seres Humanos da Faculdade de Ciências da Saúde da UnB (CEP-FS/UnB), CAAE n 36741914.4.0000.0030 e pelo Comitê de Ética em Pesquisa/FEPECS-SES-DF, CAAE $\mathrm{n}^{\circ}$ 36741914.4.3001.5553. A coleta de dados foi iniciada após a aprovação dos referidos comitês. Cada paciente foi identificado por um número, mantendo, dessa forma, o anonimato. Todos os procedimentos do estudo, bem como o TCLE (Apêndice C), foram explicados aos voluntários, antes de sua assinatura. Cada voluntário recebeu uma cópia do TCLE assinado pela pesquisadora. 


\section{RESULTADOS}

Fizeram parte deste estudo doze sobreviventes de LH, compondo o Grupo Linfoma (GL), cujos participantes eram sete mulheres e cinco homens. Ao passo que o Grupo Controle (GC) foi composto por setenta e nove indivíduos aparentemente saudáveis (GC), sendo cinquenta e sete dos indivíduos mulheres e vinte e dois homens. As características de ambos grupos estão descritas na tabela 1.

Todos os indivíduos do GL tinham concluído o tratamento há, pelo menos, seis meses, cuja média e desvio padrão do tempo de sobrevida pós tratamento foram de 4,92 $\pm 3,5$ anos enquanto a média e desvio padrão das idades dos sobreviventes no momento do diagnóstico eram $27 \pm 6,01$. Os indivíduos do GL e GC foram pareados por idade e sexo.

O teste de normalidade apresentou como resultado distribuição nãoparamétrica para a variável "Fadiga Mental"; as demais variáveis apresentaram distribuição normal.

Após análise estatística descritiva, valores de média, desvio-padrão (DP), comparação entre as médias dos grupos e tamanho do efeito (ES) das variáveis idade, altura, massa corporal, percentual de gordura e massa livre de gordura foram representados na tabela 1 a seguir. Das variáveis analisadas, apenas a variável percentual de gordura do GL apresentou diferença significativa $(p>0,05)$ para com o GC. 
Tabela 1 - Caracterização dos participantes do estudo, para o grupo linfoma e grupo controle, utilizando-se média, desvio padrão (DP), comparação entre as médias e tamanho do efeito (ES).

\begin{tabular}{lccc}
\hline \multicolumn{1}{c}{ Variáveis } & Grupo Linfoma $(\mathbf{n}=\mathbf{1 2})$ & Grupo Controle $(\mathbf{n}=\mathbf{7 9})$ \\
\hline & Média \pm DP & Média \pm DP & ES \\
Idade (anos) & $31,75 \pm 7,99$ & $31,48 \pm 8,02$ & 0,03 \\
Massa Corporal $(\mathrm{Kg})$ & $72,59 \pm 9,83$ & $68,92 \pm 14,67$ & 0,29 \\
Altura (m) & $1,7 \pm 0,80$ & $1,66 \pm 0,96$ & $2,19^{\#}$ \\
IMC & $25,21 \pm 2,71$ & $24,78 \pm 3,93$ & 0,13 \\
IAC (\%) & $28,61 \pm 4,68$ & $29,02 \pm 4,62$ & 0,09 \\
$\begin{array}{l}\text { Percentual de gordura } \\
\text { (\%) }\end{array}$ & $37,4 \pm 11,34$ & $35,62 \pm 9,7$ & 0,16 \\
$\begin{array}{l}\text { Massa Livre de Gordura } \\
\text { (Kg) }\end{array}$ & $42,88 \pm 11,34$ & & 0,12 \\
\hline
\end{tabular}

$\left.{ }^{*}\right): p \leq 0,05$.

$(\#): d \geq 0,8$

Os valores de média e desvio-padrão (DP), comparação entre as médias dos grupos e tamanho do efeito (ES) das variáveis pico de torque (PT), pico de torque relativo (PTR), distress psicológico, fadiga geral, fadiga física, fadiga mental, redução de atividade e redução da motivação estão representados da tabela 2 , a seguir. As variáveis "Fadiga Geral" e "Fadiga Mental" do GL apresentaram diferença significativa ( $p>0,05)$ para com o GC, as demais variáveis não apresentaram diferenças significativas entre os grupos. 
Tabela 2 - Dados descritivos utilizando-se média, desvio padrão (DP), comparação entre as médias e tamanho do efeito (ES) do PT, PTR, distress psicológico, fadiga geral, fadiga física, fadiga mental, redução de atividade e redução da motivação para o GL e para o GC.

\begin{tabular}{lccc}
\hline Variáveis & Grupo Linfoma $(\mathbf{n}=\mathbf{1 2})$ & Grupo Controle $(\mathbf{n}=\mathbf{7 9})$ & \\
\hline & Média \pm DP & Média \pm DP & ES \\
PT (N/m) & $184,57 \pm 55,90$ & $178,56 \pm 66,20$ & $0,98^{\#}$ \\
PTR (N/m) & $250,39 \pm 60,06$ & $257,28 \pm 79,04$ & 0,09 \\
Fadiga Geral & $14 \pm 3,90^{*}$ & $11,46 \pm 3,66$ & $4,35^{\#}$ \\
Fadiga Física & $11,23 \pm 4,33$ & $10,97 \pm 4,27$ & 0,06 \\
Fadiga Mental & $12,25 \pm 3,93^{*}$ & $9,47 \pm 4,29$ & $0,67^{\dagger}$ \\
Redução da Atividade & $10,17 \pm 3,95$ & $9,75 \pm 3,80$ & 0,15 \\
Redução da Motivação & $7,25 \pm 3,01$ & $7,22 \pm 3,04$ & 0,01 \\
Distress psicológico & $5,5 \pm 1,67$ & $4,42 \pm 2,65$ & $1,75^{\#}$ \\
\hline
\end{tabular}

$\left.{ }^{*}\right): p \leq 0,05$.

$(\dagger):$ d entre $0,4-0,7$

(\#): $d \geq 0,8$

O instrumento Termômetro de Distress traz informações sobre problemas enfrentados pela pessoa. Os problemas, em seus respectivos domínios estão representados, em relação à sua frequência, nas tabelas de 3 a 7, a seguir:

Tabela 3- Dados descritivos e frequências dos domínios do instrumento Termômetro de Distress; Domínio Problemas Práticos.

\begin{tabular}{lcccccc} 
Problemas Práticos & \multicolumn{3}{c}{ Grupo Linfoma $(\mathbf{n}=\mathbf{1 2})$} & \multicolumn{3}{c}{ Grupo Controle $(\mathbf{n}=\mathbf{7 9})$} \\
\hline Variável/Frequência\% & Sim & Não & NA & Sim & Não & NA \\
\hline Cuidar de Criança & 50 & 16,7 & 33,3 & 10 & 32,9 & 57 \\
Cuidar da casa & 33,3 & 66,7 & 0 & 20 & 67,1 & 12,7 \\
Plano de saúde/ financeiro & 50 & 33,3 & 16,7 & 20 & 57 & 22,8 \\
Transporte & 30 & 70 & 0 & 18 & 72,2 & 10,1 \\
Trabalho/ escola & 58,3 & 33,3 & 8,3 & 28 & 60,8 & 11,4 \\
\hline
\end{tabular}


Tabela 4- Dados descritivos e frequências dos domínios do instrumento Termômetro de Distress; Domínio Problemas Familiares.

\begin{tabular}{lccccccc} 
Problemas Familiares & \multicolumn{3}{c}{ Grupo Linfoma $(\mathbf{n = 1 2 )}$} & \multicolumn{2}{c}{ Grupo Controle $(\mathbf{n}=\mathbf{7 9})$} \\
\hline Variável/Frequência\% & $\operatorname{Sim}$ & Não & NA & Sim & Não & NA \\
\hline Filhos & 16,7 & 33,3 & 50 & 7,6 & 39,2 & 53,2 \\
Companheiro (a) & 27,3 & 45,4 & 27,3 & 15 & 57 & 27,8 \\
\hline
\end{tabular}

Tabela 5- Dados descritivos e frequências dos domínios do instrumento Termômetro de Distress; Domínio Envolvimento espiritual/religioso.

\begin{tabular}{lccccccc} 
& \multicolumn{4}{c}{ Grupo Linfoma $(\mathbf{n}=\mathbf{1 2})$} & \multicolumn{3}{c}{ Grupo Controle (n= 79) } \\
\cline { 2 - 7 } $\begin{array}{l}\text { Envolvimento Espiritual/ } \\
\text { Religioso }\end{array}$ & & Sim & Não & NA & Sim & Não & NA \\
\cline { 2 - 7 } & & 16,7 & 75 & 8,3 & 15 & 75,9 & 8,9 \\
\hline
\end{tabular}

Tabela 6 - Dados descritivos e frequências dos domínios do instrumento Termômetro de Distress; Domínio Problemas Emocionais.

\begin{tabular}{lcccccc} 
Problemas Emocionais & \multicolumn{3}{l}{ Grupo Linfoma $(\mathbf{n}=\mathbf{1 2})$} & \multicolumn{3}{c}{ Grupo Controle (n = 79) } \\
\hline Variável/Frequência & Sim & Não & NA & Sim & Não & NA \\
\hline Depressão & 16,7 & 75 & 8,3 & 10 & 66 & 24 \\
Medos & 41,7 & 58 & 0 & 29 & 57 & 14 \\
Nervosismo & 66,7 & 25 & 8,3 & 51 & 42 & 7,6 \\
Tristeza & 33,3 & 58 & 8,3 & 32 & 56 & 13 \\
$\begin{array}{l}\text { Preocupação } \\
\text { Perda do interesse em }\end{array}$ & 75 & 25 & 0 & 71 & 27 & 2,5 \\
atividades usuais & 33,3 & 58 & 8,3 & 18 & 72 & 10 \\
\hline
\end{tabular}


Tabela 7- Dados descritivos e frequências relativas dos domínios do instrumento Termômetro de Distress; Domínio Problemas Físicos.

\begin{tabular}{|c|c|c|c|c|c|c|}
\hline \multirow{2}{*}{$\begin{array}{c}\text { Problemas Físicos } \\
\text { Variável/Frequência \% }\end{array}$} & \multicolumn{3}{|c|}{ Grupo Linfoma $(n=12)$} & \multicolumn{3}{|c|}{ Grupo Controle $(\mathbf{n}=79)$} \\
\hline & Sim & Não & NA & Sim & Não & NA \\
\hline Aparência & 25,0 & 75,0 & 0 & 22,8 & 70,9 & 6,3 \\
\hline Tomar Banho/se vestir & 0 & 100 & 0 & 6,3 & 86,1 & 7,6 \\
\hline Respiração & 16,7 & 83,3 & 0 & 10,1 & 81,0 & 8,9 \\
\hline Mudanças ao urinar & 0 & 100 & 0 & 0,0 & 88,6 & 11,4 \\
\hline Constipação & 16,7 & 83,3 & 0 & 10,1 & 73,4 & 16,5 \\
\hline Diarreia & 8,3 & 91,7 & 0 & 6,3 & 78,5 & 15,2 \\
\hline Alimentação & 33,3 & 66,7 & 0 & 24,2 & 67,1 & 8,9 \\
\hline Fadiga & 50,0 & 50,0 & 0 & 27,8 & 64,6 & 7,6 \\
\hline Sentindo-se inchado & 33,3 & 66,7 & 0 & 16,5 & 73,4 & 10,1 \\
\hline Febre & 0 & 100 & 0 & 1,3 & 86,1 & 12,7 \\
\hline Dar uma volta/circular & 8,3 & 91,7 & 0 & 2,5 & 86,1 & 11,4 \\
\hline Indigestão & 16,7 & 83,3 & 0 & 19 & 69,6 & 11,4 \\
\hline Memória/ Concentração & 58,3 & 41,7 & 0 & 29,1 & 65,8 & 5,1 \\
\hline Mucosite/afta & 0 & 100 & 0 & 6,3 & 79,7 & 13,9 \\
\hline Náusea & 16,7 & 83,3 & 0 & 5,1 & 82,3 & 12,7 \\
\hline $\begin{array}{l}\text { Nariz seco/ } \\
\text { Congestionado }\end{array}$ & 25 & 75 & 0 & 21,5 & 65,8 & 11,4 \\
\hline Dores & 50 & 50 & 0 & 25,6 & 64,1 & 9,0 \\
\hline Sexual & 16,7 & 83,3 & 0 & 22,8 & 65,8 & 11,4 \\
\hline Pele seca/ coceira & 16,7 & 83,3 & 0 & 25,3 & 65,8 & 8,9 \\
\hline Dormir & 33,3 & 66,7 & 0 & 7,6 & 79,7 & 12,7 \\
\hline Mãos/ pés formigando & 25 & 75 & 0 & 11,4 & 75,9 & 12,7 \\
\hline
\end{tabular}


Os valores das correlações paramétricas entre composição corporal e as variáveis fadiga (e seus domínios) e distress psicológico do GL e os valores da correlação não-paramétrica do domínio Fadiga Mental da varável fadiga estão representados da tabela 8 abaixo.

Tabela 8- Dados das correlações entre composição corporal e as variáveis fadiga e distress psicológico do GL

\begin{tabular}{lcccccc}
\hline Parâmetros & $\begin{array}{c}\text { Fadiga } \\
\text { Geral }\end{array}$ & $\begin{array}{c}\text { Fadiga } \\
\text { Física }\end{array}$ & $\begin{array}{c}\text { Fadiga } \\
\text { Mental }\end{array}$ & $\begin{array}{c}\text { Redução } \\
\text { da } \\
\text { Atividade }\end{array}$ & $\begin{array}{c}\text { Redução da } \\
\text { Motivação }\end{array}$ & Distress \\
\hline IMC & 0,062 & $-0,005$ & $-0,181$ & $-0,422$ & $-0,513^{\alpha}$ & $-0,33$ \\
IAC & 0,015 & $-0,054$ & $-0,167$ & $-0,171$ & $-0,125$ & 0,015 \\
$\begin{array}{l}\text { \% de } \\
\text { Gordura }\end{array}$ & 0,321 & 0,252 & $-0,114$ & $-0,111$ & $-0,263$ & 0,027 \\
$\begin{array}{l}\text { Massa Livre } \\
\text { de Gordura }\end{array}$ & $-0,237$ & $-0,217$ & 0,050 & $-0,315$ & $-0,492$ &,- 0149 \\
\hline
\end{tabular}

$\left(^{*}\right): p \leq 0,05$

$(\alpha): r \geq 0,5$.

A partir da análise dos valores de correlação demonstrados na tabela 8, é visto que não houve correlações significativas entre as variáveis de composição corporal e as variáveis distress psicológico e fadiga (em seus domínios) para com o GL. Houve apenas um tamanho do efeito relevante entre as variáveis IMC e o domínio Redução da Motivação.

Os valores das correlações paramétricas entre composição corporal e as variáveis fadiga (e seus domínios) e distress psicológico do GC e os valores da correlação não-paramétrica do domínio Fadiga Mental da varável fadiga estão representados na tabela 9 , a seguir. 
Tabela 9 - Dados das correlações entre composição corporal e as variáveis fadiga e distress psicológico do GC

\begin{tabular}{lcccccc}
\hline Parâmetros & $\begin{array}{c}\text { Fadiga } \\
\text { Geral }\end{array}$ & $\begin{array}{c}\text { Fadiga } \\
\text { Física }\end{array}$ & $\begin{array}{c}\text { Fadiga } \\
\text { Mental }\end{array}$ & $\begin{array}{c}\text { Redução da } \\
\text { Atividade }\end{array}$ & $\begin{array}{c}\text { Redução da } \\
\text { Motivação }\end{array}$ & Distress \\
\hline IMC & $0,358^{* *}$ & $0,248^{*}$ & 0,121 & 0,070 & $0,0227^{*}$ & $0,396^{* *}$ \\
IAC & $0,372^{* *}$ & $0,299^{* *}$ & 0,141 & 0,122 & $0,316^{* *}$ & $0,336^{\star *}$ \\
$\%$ de Gordura & $0,486^{* *}$ &, $475^{\star *}$ & 0,108 & 0,152 & 0,186 & $0,407^{* *}$ \\
$\begin{array}{l}\text { Massa Livre } \\
\text { de Gordura }\end{array}$ & $-0,069$ & $-0,159$ & $-0,006$ & $-0,079$ & $-0,056$ & 0,047 \\
\hline
\end{tabular}

$\left(^{*}\right): p \leq 0,05$.

$\left({ }^{* *}\right): p \leq 0,005$.

A partir da análise dos valores de correlação demonstrados na tabela 9 , os dados do GC apresentaram correlações classificadas como fracas e moderadas. $O$ IMC apresentou correlação fraca com as variáveis Distress, Fadiga Geral, Fadiga Física e Redução da Motivação; o IAC apresentou correlação fraca com as variáveis Distress, Fadiga Geral, Fadiga Física e Redução da Motivação; enquanto o percentual de gordura apresentou correlação moderada com as variáveis Distress, Fadiga Geral, Fadiga Física e Redução da Motivação; o IAC apresentou correlação fraca com as variáveis Distress, Fadiga Geral e Fadiga Física.

Os valores das correlações paramétricas entre PT e PTR e as variáveis fadiga (e seus domínios) e distress psicológico e os valores da correlação nãoparamétrica do domínio Fadiga Mental da varável fadiga do GL estão representados na tabela 10.

Tabela 10 - Dados das correlações entre PT e PTR e as variáveis fadiga e distress psicológico do GL.

\begin{tabular}{lcccccc}
\hline Parâmetros & $\begin{array}{c}\text { Fadiga } \\
\text { Geral }\end{array}$ & $\begin{array}{c}\text { Fadiga } \\
\text { Física }\end{array}$ & $\begin{array}{c}\text { Fadiga } \\
\text { Mental }\end{array}$ & $\begin{array}{c}\text { Redução da } \\
\text { Atividade }\end{array}$ & $\begin{array}{c}\text { Redução da } \\
\text { Motivação }\end{array}$ & Distress \\
\hline PT & $-0,426$ & $-0,291$ & $-0,036$ & $-0,247$ & $-0,609^{* \alpha}$ & $-0,108$ \\
PTR & $-0,474$ & $-0,503 \alpha$ & $-0,043$ & $-0,091$ & $-0,454$ & 0,025 \\
\hline
\end{tabular}

$\left({ }^{*}\right): p \leq 0,05$.

$(\alpha): r \geq 0,5$. 
A partir da análise dos valores de correlação demonstrados na tabela 10 , os dados do GL apresentaram uma correlação classificada como moderada entre PT e Redução da Motivação, enquanto as demais variáveis não se correlacionaram.

Os valores das correlações paramétricas entre PT e PTR e as variáveis fadiga (e seus domínios) e distress psicológico e os valores da correlação nãoparamétrica do domínio Fadiga Mental da varável fadiga do GC estão representados na tabela 11.

Tabela 11 - Dados das correlações entre PT e PTR e as variáveis fadiga e distress psicológico do GC.

\begin{tabular}{lcccccc}
\hline Parâmetros & $\begin{array}{c}\text { Fadiga } \\
\text { Geral }\end{array}$ & $\begin{array}{c}\text { Fadiga } \\
\text { Física }\end{array}$ & $\begin{array}{c}\text { Fadiga } \\
\text { Mental }\end{array}$ & $\begin{array}{c}\text { Redução da } \\
\text { Atividade }\end{array}$ & $\begin{array}{c}\text { Redução da } \\
\text { Motivação }\end{array}$ & Distress \\
\hline PT & $-0,162$ & $-0,241^{*}$ & $-0,079$ & $-0,146$ & $-0,103$ & 0,075 \\
PTR & $-0,409^{* *}$ & $-0,437^{* *}$ & $-0,147$ & $-0,255^{*}$ & $-0,158$ & $-0,188$ \\
\hline$\left(^{*}\right): p \leq 0,05$. & & & & & & \\
$\left(^{* *}\right): p \leq 0,005$. \\
$(\alpha): r \geq 0,5$.
\end{tabular}

A partir da análise dos valores de correlação demonstrados na tabela 11, os dados do GC apresentaram duas correlações negativas classificadas como moderadas, entre PTR e Fadiga Geral e entre PTR e Fadiga Física, PTR apresentou correlação negativa fraca com a variável Redução da Atividade, enquanto a variável PT apresentou correlação negativa fraca com a variável Fadiga Física; as demais variáveis não se correlacionaram.

Os valores das correlações entre composição corporal - IMC, IAC, Percentual de gordura e massa livre de gordura (MLG) e pico de torque em sobreviventes de LH e em pessoas aparentemente saudáveis estão representados na tabela 12. 
Tabela 12 - Dados das correlações entre PT e PTR e composição corporal dos grupos Linfoma e Controle.

\begin{tabular}{cccccc}
\hline Grupo & Parâmetros & IMC & IAC & \% de Gordura & MLG \\
\hline \multirow{2}{*}{ GL } & PT & 0,150 & $-0,638^{* \alpha}$ & $-0,784^{* * \alpha}$ & $0,913^{\star * \alpha}$ \\
& PTR & $-0,207$ & $-0,596^{* \alpha}$ & $-0,835^{* \star \alpha}$ & $0,708^{* \alpha}$ \\
\hline \multirow{2}{*}{ GC } & PT & $0,280^{*}$ & $-0,374^{*}$ & $-0,414^{*}$ & $0,821^{* \star \alpha}$ \\
& PTR & $-0,244^{*}$ & $-0,374^{*}$ & $-0,496^{*}$ & $0,415^{* *}$
\end{tabular}

$\left({ }^{*}\right): p \leq 0,05$.

$\left({ }^{* *}\right): p \leq 0,005$.

$(\alpha): r \geq 0,5$.

A partir da análise dos valores de correlação demonstrados na tabela 12, em relação ao PT, PTR e à composição corporal, o GL apresentou correlações negativas moderadas entre as variáveis PT e IAC e entre PTR e IAC e percentual de gordura, enquanto a variável PT apresentou correlação forte com o percentual de gordura. Nesta mesma análise, o GC apresentou correlação negativa fraca entre PT e IAC; correlação fraca positiva entre PT e IMC; correlações negativas fracas entre PTR e as variáveis IMC e IAC, enquanto as variáveis PT e PTR apresentaram correlações negativas moderadas com o percentual de gordura.

Os valores das correlações entre distress psicológico e os domínios de fadiga em sobreviventes de LH e em pessoas aparentemente saudáveis estão representados nas tabelas 13 .

Tabela 13 - Dados das correlações entre Distress psicológico e os domínios da variável fadiga dos grupos Linfoma e Controle.

\begin{tabular}{|c|c|c|c|c|c|c|}
\hline Grupo & Parâmetros & $\begin{array}{c}\text { Fadiga } \\
\text { Geral }\end{array}$ & $\begin{array}{l}\text { Fadiga } \\
\text { Física }\end{array}$ & $\begin{array}{l}\text { Fadiga } \\
\text { Mental }\end{array}$ & $\begin{array}{l}\text { Redução } \\
\text { da } \\
\text { Atividade }\end{array}$ & $\begin{array}{c}\text { Redução da } \\
\text { Motivação }\end{array}$ \\
\hline GLyn & Distress & $0,637^{\star \alpha}$ & 0,456 & 0,450 & $0,603^{* a}$ & $0,583^{* a}$ \\
\hline GCon & & $0,451^{* *}$ & $0,357^{* \star}$ & $0,239^{*}$ & 0,038 & $0,258^{*}$ \\
\hline
\end{tabular}


A partir da análise dos valores de correlação demonstrados na tabela 13, relativos ao Distress e aos domínios da Fadiga, o GL apresentou correlações moderadas entre distress e os domínios Fadiga Geral, Redução da Atividade e Redução da Motivação; ao passo que o GC apresentou correlação moderada entre Distress e Fadiga Geral e correlações fracas entre Distress e Fadiga Física, Fadiga Mental e Redução da Motivação. 


\section{DISCUSSÃO}

O presente estudo teve por objetivo avaliar se existem associações entre composição corporal, força, fadiga e distresse psicológico em sobreviventes de LH e comparar estes resultados aos resultados de pessoas aparentemente saudáveis com características similares tais como idade e gênero. Para tanto, houve coleta desses dados de 12 sobreviventes e de 79 indivíduos aparentemente saudáveis.

Sobre a composição corporal, o grupo acometido pelo linfoma apresentou maior percentual de gordura e a literatura relata que o aumento de tecido adiposo é uma alteração não favorável que pode ser decorrente do processo da doença e do tratamento com intuito curativo, principalmente a quimioterapia (VISOVSKY, 2006). Nesse sentido, sabe-se também que um percentual de gordura elevado traz consequências sistêmicas que reduzem a qualidade de vida do sobrevivente, piora o prognóstico dos sobreviventes e aumenta a incidência de mortalidade. Essa condição parece estar relacionada ao aumento de citocinas inflamatórias, aumento da incidência de comorbidades como hipertensão, diabetes tipo II e alterações endócrinas (MARMOT, 2007; DAL MASO, 2008; PAXTON et al., 2012.HEYLER et al., 2010; SALIGAN et al, 2015; SHA et al, 2015). Além disso, outros estudos relatam que mulheres com excesso de peso e obesidade podem ser submetidas a um tratamento quimioterápico com doses inferiores as preconizadas, o que reduziria a eficiência do tratamento e comprometeria a sobrevida, além aumentar o risco de incidência de, pelo menos, dez tipos de câncer (CALLE, 2003; REEVES, 2007; GREENMAN, JAGIELSKI e GRIGGS, 2008), não sendo, contudo, estes achados unânimes (BREWSTER et al., 2011).

No que tange ao tecido muscular e, consequentemente, à capacidade de gerar força, sabe-se que o tratamento curativo pode trazer a diminuição do tecido muscular, podendo gerar sarcopenia e mesmo a condição de caquexia (TISDALE, 2002; ACHARYYA, 2005; NUNES, 2007) enquanto a doença e a toxicidade desse tratamento podem acarretar alterações negativas na função e metabolismo de tal tecido, visto que há relatos de reações como aumento da acidose metabólica, hipóxia, incremento do metabolismo glicolítico, disfunção da função mitocondrial muscular (DEMARK-WAHNEFRIED et al., 1997; AL-MAJID, 2001; FREEDMAN, 2004; WOLFE, 
2006; VIEIRA, 2015). Os resultados deste estudo mostram que o PT do grupo linfoma apresentou-se maior que o PT do grupo controle, porém, quando se analisa o PTR que relativiza a força gerada ao peso corporal - o resultado não se mostra expressivo, sendo coerente com o que a literatura relata até então. E, acredita-se ainda, que o tempo de recuperação da musculatura pelo esforço gerado ao sobrevivente de linfoma seja maior que na população aparentemente saudável (VALERIANO, 2015).

Em relação aos domínios da variável fadiga e as diferenças entre as médias dos grupos, estudos de curto e longo prazo mostram que os sobreviventes de LH apresentam maiores níveis de fadiga que indivíduos aparentemente saudáveis, além de uma diminuição dos níveis de qualidade de vida, dos níveis de energia e, ainda, complicações cardiopulmonares, dentre outras, nesses sobreviventes (BROWN, 2003 ; KHIMANI, 2012; GATIBONI, 2014), sendo assim, a diferença de médias dos grupos deste estudo encontradas nas variáveis fadiga geral e fadiga mental, mostram que os sobreviventes apresentam maior índice de fadiga que indivíduos aparentemente saudáveis, convergem com dados já relatados pela literatura, porém, esperava-se encontrar níveis de significância semelhantes nos demais domínios do questionário IMF-20, como encontrados em estudos anteriores (RUFFER, 2003).

Os motivos pelos quais os demais domínios da fadiga não são significativamente diferentes entre os grupos nesse estudo ainda não estão esclarecidos, podendo-se especular que a amostra de sobreviventes seja composta predominantemente por pessoas jovens e que consideram-se fisicamente ativas, ou também pelo fato da fadiga ter sido avaliada por um questionário, ou seja, de maneira subjetiva, podendo o sobrevivente se sentir compelido à responder positivamente quando questionado sobre sua condição de saúde e disposição. Infelizmente, a literatura científica ainda carece de estudos com essa malignidade especificamente que analisem variáveis de força e composição corporal e as correlacionem com dados de fadiga (tanto de maneira subjetiva quanto de maneira fisiológica) e o distresse psicológico - dentre outras variáveis de caráter subjetivo/psicológico que já se mostraram presentes nesta população como depressão, qualidade de vida relacionada à saúde, níveis de atividade física etc.

Por ser uma condição crônica, o LH traz ao sobrevivente a necessidade de uma série de ajustes em diversos domínios de sua vida - físicos, emocionais, 
cognitivos, comportamentais, interpessoais, entre outros. Todo o processo de tratamento, seus efeitos físicos e emocionais são fatores distressantes para o sobrevivente que tendem a diminuir sua qualidade de vida e requerem assistência multidisciplinar, até pela vulnerabilidade em que podem se encontrar (LUKIN e LARSEN, 2006; LOURENÇÃO, 2010).

Nesse sentido, outra variável subjetiva analisada neste trabalho, o distresse psicológico, apresenta correlações significativas e relevantes com as variáveis de composição corporal IMC, IAC e percentual de gordura e, ainda, apresentou associações com os domínios fadiga geral, redução da atividade e redução da motivação para o grupo controle. Porém, esperava-se que resultados semelhantes fossem encontrados para a população de sobreviventes sendo que, para o GL apenas o distresse psicológico se correlaciona com os domínios da fadiga - e não as variáveis de composição corporal. A literatura ainda carece de estudos que avaliem essas variáveis nos sobreviventes de linfoma, tal como existem para os sobreviventes de câncer de mama ou colo-retal. Especula-se, assim, que as alterações trazidas por esta malignidade não sejam tão semelhantes às alterações esperadas para outros tipos de câncer. É possível que para o linfoma e seus sobreviventes as alterações metabólicas esperadas de um tumor não sejam tão degradantes quanto as que ocorrem em outros tipos de cânceres tumorais e, ainda, é possível que o tratamento usado com esta doença, até o estadiamento III, não seja tão devastador, ou não gere tantos efeitos crônicos, quanto os tratamentos para os tipos de câncer que possuem tumores sólidos ou que sejam considerados mais agressivos.

A preocupação com essa variável se faz necessária devido a suas associações já relatadas pela literatura com sintomas qualitativos e subjetivos que interferem diretamente na qualidade de vida relacionada à saúde do sobrevivente, como depressão e ansiedade (DEIMILING, 2002; LUFT, 2007; MORASSO, 2010;). presente estudo, corroborando com anteriores, mostra que a ferramenta para obtenção dos níveis de distresse psicológico deve ser apenas um meio de investigação acerca de sintomas psicossociais, visto que possui suas limitações quanto ao seu alcance na gama de sinais e sintomas que podem acometer essa população. Visto que compreender como os sobreviventes gerem o impacto do câncer e a experiência das transformações na vida torna-se relevante para todos os profissionais de saúde, de modo a potenciar uma sobrevivência de qualidade (PINTO 
e RIBEIRO, 2007). Nesse sentido, partir dos resultados obtidos nesse estudo, sugerese que haja novas investigações que utilizem mais de um parâmetro para a análise da fadiga, além de questionários e dados subjetivos, pois acredita-se que mais dados acerca dessa variável apresente resultados mais fidedignos e esclareçam melhor as associações da fadiga com demais variáveis tanto físicas quanto psicológicas.

Ainda em relação ao distresse psicológico, não houve diferença significativa entre os níveis de distresse dos dois grupos, porém, ao analisarmos a lista de problemas - não somente a pontuação do termômetro - é possível verificar preocupações presentes de maneira expressiva nos sobreviventes que não se mostram relevantes para o grupo controle. Variáveis que envolvem preocupação acerca do estado de saúde, principalmente, como medos, nervosismo, preocupação, trabalho, plano de saúde, fadiga, memória/concentração, náuseas são consideravelmente mais frequentes nos sobreviventes mesmo que, talvez, não pareçam tão expressivas se for analisada apenas a nota do termômetro. Tal análise traz a ideia de que, apesar de preocupações e sentimentos angustiantes se fazerem presentes no GL, a nota final não ser tão diferente do GC pode ser sinal de haver a presença, também, de sentimentos como resiliência e temperança nestes indivíduos.

Esta hipótese precisa ser considerada nesse sentido, como um conjunto de mudanças emocionais e comportamentais que a luta contra a doença acarreta no sobrevivente. O processo de cura pode trazer sentimentos como o da resiliência e esperança, que auxilia o sobrevivente no processo de sobrevida os ajudando a desenvolver a capacidade de lidar positivamente com adversidades e obstáculos (SEMEDO, 2011; LOPES, 2014). Esses fenômenos quando analisados a partir que questionários simples e objetivos, sob pouca ou nenhuma especulação adicional, podem não sobressair-se e não espelhar, de fato, a realidade em que os sobreviventes se encontram. Portanto, acredita-se que, apesar de ser uma doença crônica e trazer consigo tantos efeitos maléficos, distressantes e alterações desfavoráveis, a experiência de se vivenciar o câncer não significa necessariamente um aviso de morte, mas pode significar um ponto de mudança da vida do indivíduo (LESHAN, 1992).

Ademais, recomenda-se a confecção de novos estudos, especificamente com sobreviventes de $\mathrm{LH}$, acerca de variáveis de composição corporal e força 
associadas a variáveis de caráter psicológico e/ou subjetivo, investigando o impacto de possíveis alterações não favoráveis destas varáveis na qualidade de vida relacionada à saúde do sobrevivente para que, assim, seja possível planejar e trabalhar a promoção e educação em saúde desta população e dos profissionais pluridisciplinares envolvidos em seus cuidados e sobrevida. 


\section{CONCLUSÃO}

Os resultados desse estudo confirmam que os sobreviventes de $\mathrm{LH}$ possuem maior percentual de gordura, maiores níveis de fadiga e maior distresse psicológico que uma população de indivíduos aparentemente saudáveis; possuem uma frequência maior de preocupações com problemas de ordem de saúde e do cotidiano. O maior percentual de gordura parece não se associar com os índices de fadiga e distresse relatados pelo GL, seus os níveis de força parecem ser apenas parcialmente associados aos domínios da fadiga, porém, estão negativamente relacionados ao percentual de gordura. Além disso, o distresse psicológico dos sobreviventes se associa consideravelmente aos níveis de fadiga, assim como em indivíduos aparentemente saudáveis.

É preciso considerar que o estudo possui amostra de sobreviventes de $\mathrm{LH}$ reduzida e pontos fracos como não possuir dados de variáveis como fadiga muscular, marcadores inflamatórios sanguíneos e dados pré-tratamento. No entanto, é possível que a doença e seu tratamento não afetem de forma tão negativa os níveis de força e componentes da composição corporal dos sobreviventes, mas a presença de fadiga e distresse psicológico precisa ser acompanhada, visto serem domínios que afetam a qualidade de vida do indivíduo. 


\section{REFERÊNCIAS}

ACHARYYA, Swarnali; GUTTRIDGE, Denis C. Cancer cachexia signaling pathways continue to emerge yet much still points to the proteasome. Clinical Cancer Research, v. 13, n. 5, p. 1356-1361, 2007.

AL-MAJID, Sadeeka; MCCARTHY, Donna O. Cancer-induced fatigue and skeletal muscle wasting: the role of exercise. Biological research for nursing, v. 2, n. 3, p. 186-197, 2001.

AMERICAN CANCER SOCIETY. Cancer Facts \& Figures 2013. Atlanta: American Cancer Society; 2013.

ANDRADE, Viviane; SAWADA, Namie Okino; BARICHELLO, Elizabeth. Qualidade de vida de pacientes com câncer hematológico em tratamento quimioterápico. Revista da Escola de Enfermagem da USP, v. 47, n. 2, p. 355-361, 2013.

ANSELL, Stephen M. Hodgkin lymphoma: 2012 update on diagnosis, risk-stratification, and management. American journal of hematology, v. 87, n. 12, p. 1096-1103, 2012.

ARGILÉS, Josep M. et al. Cancer cachexia: understanding the molecular basis. Nature reviews Cancer, v. 14, n. 11, p. 754-762, 2014.

BAPTISTA, Renata Lyrio R. et al. Psychometric properties of the multidimensional fatigue inventory in Brazilian Hodgkin's lymphoma survivors. Journal of pain and symptom management, v. 44, n. 6, p. 908-915, 2012.

BARSEVICK, Andrea et al. I'm so tired: biological and genetic mechanisms of cancer-related fatigue. Quality of Life Research, v. 19, n. 10, p. 1419-1427, 2010.

BAUM, Andrew; GRUNBERG, Neil E.; SINGER, Jerome E. The use of psychological and neuroendocrinological measurements in the study of stress. Health psychology, v. 1, n. 3, p. $217,1982$.

BOTEGA, Neury J. et al. Mood disorders among medical in-patients: a validation study of the hospital anxiety and depression scale (HAD). Revista de Saúde Pública, v. 29, n. 5, p. 359363, 1995.

BOWER, Julienne E. et al. Fatigue in breast cancer survivors: occurrence, correlates, and impact on quality of life. Journal of Clinical Oncology, v. 18, n. 4, p. 743-743, 2000.

BREWSTER, A. M. et al. The impact of obesity on receipt of adjuvant chemotherapy for breast cancer in the National Comprehensive Cancer Network (NCCN) centers. Breast cancer research and treatment, v. 130, n. 3, p. 897-904, 2011.

BROWN, Linda F.; KROENKE, Kurt. Cancer-related fatigue and its associations with depression and anxiety: a systematic review.Psychosomatics, v. 50, n. 5, p. 440-447, 2009.

BULTZ, Barry D.; CARLSON, Linda E. Emotional distress: the sixth vital sign in cancer care. Journal of Clinical Oncology, v. 23, n. 26, p. 6440-6441, 2005. 
BRYANT, Ashley Leak; WALTON, AnnMarie Lee; PHILLIPS, Brett. Cancer-related fatigue: scientific progress has been made in 40 years. Clinical journal of oncology nursing, v. 19, n. 2, p. 137, 2015.

CARBONE, Paul P. et al. Report of the committee on Hodgkin's disease staging classification. Cancer research, v. 31, n. 11, p. 1860-1861, 1971.

CARLSON, Linda E.; BULTZ, Barry D. Cancer distress screening: needs, models, and methods. Journal of psychosomatic research, v. 55, n. 5, p. 403-409, 2003.

CARLSON, L. E. et al. High levels of untreated distress and fatigue in cancer patients. British Journal of cancer, v. 90, n. 12, p. 2297-2304, 2004.

CELLA, David F.; TROSS, Susan. Psychological adjustment to survival from Hodgkin's disease. Journal of Consulting and Clinical Psychology, v. 54, n. 5, p. 616, 1986.

CHEN X, Lu W, Zheng W, Gu K, Chen Z, Zheng Y, Shu XO. Obesity and weight change in relation to breast cancer survival. Breast Cancer Res Treat. 2010; 122:823-33.

COHEN, Jacob. A power primer. Psychological bulletin, v. 112, n. 1, p. 155, 1992.

CULL, A. et al. What do cancer patients mean when they complain of concentration and memory problems?. British journal of cancer, v. 74, n. 10, p. 1674, 1996.

DAL MASO, Luigino et al. Effect of obesity and other lifestyle factors on mortality in women with breast cancer. International journal of cancer, v. 123, n. 9, p. 2188-2194, 2008.

DANCEY, Christine \& REIDY, John. (2006), Estatística Sem Matemática para Psicologia: Usando SPSS para Windows. Porto Alegre, Artmed.

DE ALBUQUERQUE, Karla Alexsandra; DE MATTOS PIMENTA, Cibele Andrucioli. Distress do paciente oncológico: prevalência e fatores associados na opinião de familiares/Distress of cancer patients: prevalence and associated factors in the opinion of family/Angustia de los pacientes con cáncer: prevalencia y factores asociados en la opinión de la familia. Revista Brasileira de Enfermagem, v. 67, n. 5, p. 744, 2014.

DECAT, Cristiane Sant'Anna; LAROS, Jacob Arie; ARAUJO, Tereza Cristina Cavalcanti Ferreira de. Termômetro de Distress: validação de um instrumento breve para avaliação diagnóstica de pacientes oncológicos. Psico USF, v. 14, n. 3, p. 253-260, 2009.

DEIMLING, Gary T. et al. Cancer survivorship and psychological distress in later life. PsychoOncology, v. 11, n. 6, p. 479-494, 2002.

DEMARK-WAHNEFRIED, Wendy et al. Preventing sarcopenic obesity among breast cancer patients who receive adjuvant chemotherapy: results of a feasibility study. Clinical Exercise Physiology, v. 4, n. 1, p. 44, 2002.

DIMEO, Fernando Carlos. Effects of exercise on cancer-related fatigue.Cancer, v. 92, n. S6, p. 1689-1693, 2001.

DOMINGUEZ, A. Rueda et al. Treatment of stage I and II Hodgkin's lymphoma with ABVD chemotherapy: results after 7 years of a prospective study. Annals of Oncology, v. 15, n. 12, p. 1798-1804, 2004. 
DROUIN, Joshua M. et al. Reliability and validity of the Biodex system 3 pro isokinetic dynamometer velocity, torque and position measurements. European journal of applied physiology, v. 91, n. 1, p. 22-29, 2004.

ELSAYED, Ahmed Ali et al. Prognostic significance of CD20 expression and Epstein-Barr virus (EBV) association in classical Hodgkin lymphoma in Japan: A clinicopathologic study. Pathology international, v. 64, n. 7, p. 336-345, 2014.

ESTIMATIVA, I. N. C. A. Incidência do Câncer no Brasil/Instituto Nacional de Câncer José Alencar Gomes da Silva, Coordenação de Prevenção e Vigilância. 2014. Rio de Janeiro. Disponível http://www. inca. gov. br/estimativa/2014/. Acesso em, v. 20, 2014.

EVANS, William J. et al. Cachexia: a new definition. Clinical nutrition, v. 27, n. 6, p. 793-799, 2008.

EWERTZ, Marianne et al. Effect of obesity on prognosis after early-stage breast cancer. Journal of Clinical Oncology, v. 29, n. 1, p. 25-31, 2011.

FEARON, Kenneth C. et al. Definition of cancer cachexia: effect of weight loss, reduced food intake, and systemic inflammation on functional status and prognosis. The American journal of clinical nutrition, v. 83, n. 6, p. 1345-1350, 2006.

FINSTERER, Josef. Biomarkers of peripheral muscle fatigue during exercise.BMC Musculoskeletal Disorders, v. 13, n. 1, p. 1, 2012.

FOBAIR, Patricia et al. Psychosocial problems among survivors of Hodgkin's disease. Journal of clinical Oncology, v. 4, n. 5, p. 805-814, 1986.

FOULADIUN, Marita et al. Body composition and time course changes in regional distribution of fat and lean tissue in unselected cancer patients on palliative care-correlations with food intake, metabolism, exercise capacity, and hormones. Cancer, v. 103, n. 10, p. 2189-2198, 2005.

FREEDMAN, R. J. et al. Weight and body composition changes during and after adjuvant chemotherapy in women with breast cancer. The Journal of Clinical Endocrinology \& Metabolism, v. 89, n. 5, p. 2248-2253, 2004.

GADEA, E. et al. Importance of metabolic changes induced by chemotherapy on prognosis of early-stage breast cancer patients: a review of potential mechanisms. Obesity Reviews, v. 13, n. 4, p. 368-380, 2012.

GANDHI, Maher K.; TELLAM, Judy T.; KHANNA, Rajiv. Epstein-Barr virus-associated Hodgkin's lymphoma. British journal of haematology, v. 125, n. 3, p. 267-281, 2004.

GATIBONI, Tanira. Revisão epidemiológica com ênfase nos efeitos tardios pós primeira linha de tratamento para linfoma de Hodgkin em pacientes acompanhados no serviço de oncologia pediátrica do Hospital de Clínicas de Porto Alegre no período de 1995 a 2012. 2014.

GOLDMAN, Lee; AUSIELLO, Dennis (Ed.). Cecil-Tratado de Medicina Interna, 2v. Elsevier Brasil, 2005.

GOTTI, Manuel et al. Therapy-related late adverse events in Hodgkin's lymphoma. Lymphoma, v. 2013, 2013. 
GREENMAN, Christopher G.; JAGIELSKI, Christina H.; GRIGGS, Jennifer J. Breast cancer adjuvant chemotherapy dosing in obese patients. Cancer, v. 112, n. 10, p. 2159-2165, 2008.

HEUTTE, Natacha et al. Quality of life after successful treatment of early-stage Hodgkin's lymphoma: 10-year follow-up of the EORTC-GELA H8 randomised controlled trial. The lancet oncology, v. 10, n. 12, p. 1160-1170, 2009.

HELYER, Lucy K. et al. Obesity is a risk factor for developing postoperative lymphedema in breast cancer patients. The breast journal, v. 16, n. 1, p. 48-54, 2010.

HOFFBRAND, A. Victor; MOSS, P. A. Fundamentos em hematologia. In:Fundamentos em hematologia. Artmed, 2013.

HOLLEY, Sandra. Cancer-Related Fatigue. Cancer practice, v. 8, n. 2, p. 87-95, 2000.

HOLLAND, Jimmie C.; BULTZ, Barry D. The NCCN guideline for distress management: a case for making distress the sixth vital sign. Journal of the National Comprehensive Cancer Network, v. 5, n. 1, p. 3-7, 2007. INCA, 2014.

HOPPE, Richard T. et al. Hodgkin lymphoma, version 2.2012 featured updates to the NCCN guidelines. Journal of the National Comprehensive Cancer Network, v. 10, n. 5, p. 589597, 2012.

JONES, Whitney C. et al. Understanding distress in posttreatment adult leukemia and lymphoma survivors: a lifespan perspective. Journal of psychosocial oncology, v. 33, n. 2, p. 142-162, 2015.

KHAN, Gulfaraz; NORTON, Andrew J.; SLAVIN, Gerard. Epstein-barr virus in hodgkin disease relation to age and subtype. Cancer, v. 71, n. 10, p. 3124-3129, 1993.

KHIMANI, N. et al. Influence of new late effects on quality of life over time in Hodgkin lymphoma Survivors: a longitudinal survey study. Annals of oncology, p. mds243, 2012.

KIM, Seung Jun et al. Prevalence and associated factors of psychological distress among Korean cancer patients. General hospital psychiatry, v. 33, n. 3, p. 246-252, 2011.

KÜPPERS, R. et al. Tracing B cell development in human germinal centres by molecular analysis of single cells picked from histological sections. The EMBO Journal, v. 12, n. 13, p. 4955, 1993.

KÜPPERS, Ralf. The biology of Hodgkin's lymphoma. Nature Reviews Cancer, v. 9, n. 1, p. 15-27, 2009.

LAVOY, Emily CP; FAGUNDES, Christopher P.; DANTZER, Robert. Exercise, inflammation, and fatigue in cancer survivors. Exercise immunology review, v. 22, p. 82, 2016.

LEEUWEN-SEGARCEANU, Elena M. et al. Progressive muscle atrophy and weakness after treatment by mantle field radiotherapy in Hodgkin lymphoma survivors. International Journal of Radiation Oncology* Biology* Physics, v. 82, n. 2, p. 612-618, 2012.

LESHAN, Lawrence. Câncer Como Ponto de Mutacao, O. Grupo Editorial Summus, 1992.

LOGE, Jon Håvard; EKEBERG, Øivind; KAASA, Stein. Fatigue in the general Norwegian population: normative data and associations. Journal of psychosomatic research, v. $45, n$. 1, p. 53-65, 1998. 
LOPES, M. S. N.; DOBBIN, J. A.; CARNEIRO-PROIETTI, A. B. F. Leucemia/linfoma de células T do Adulto (ATL): um protótipo de doença viral em hematologia. Carneiro-Proietti ABF, org. HTLV. Belo Horizonte: Fundação Centro de Hematologia e Hemoterapia de Minas Gerais, p. 93-114, 2006.

LOPES, Katia. O bem-estar espiritual e resiliência em doentes oncológicos. 2014. Tese de Doutorado.

LOURENÇÃO, Vanessa Cristina; DOS SANTOS JUNIOR, Randolfo; LUIZ, Andreia Mara Gonçalves. Aplicações da terapia cognitivo-comportamental em tratamentos de câncer. Revista Brasileira de Terapias Cognitivas, v. 5, n. 2, p. 59-72, 2009.

LUBKIN, Ilene Morof; LARSEN, Pamala D. Chronic illness: Impact and interventions. Jones \& Bartlett Learning, 2006.

LUCÍA, Alejandro; EARNEST, Conrad; PÉREZ, Margarita. Cancer-related fatigue: can exercise physiology assist oncologists?. The lancet oncology, v. 4, n. 10, p. 616-625, 2003.

MACHADO, Mariana et al. Linfoma de Hodgkin-Conceitos actuais. Medicina Interna, v. 11, n. 4, p. 207-215, 2004.

MAKARI-JUDSON, Grace; JUDSON, Christopher H.; MERTENS, Wilson C. Longitudinal patterns of weight gain after breast cancer diagnosis: observations beyond the first year. The breast journal, v. 13, n. 3, p. 258-265, 2007.

MARMOT, Michael et al. Food, nutrition, physical activity, and the prevention of cancer: a global perspective. 2007.

MARTA, Gustavo Nader; ABREU, Carlos Eduardo Cintra Vita. Linfoma de Hodgkin: aspectos práticos da abordagem radioterápica. Revista da Faculdade de Ciências Médicas de Sorocaba. ISSN eletrônico 1984-4840, v. 14, n. 1, p. 1-4, 2012.

METZGER, Monika L. et al. Association between radiotherapy vs no radiotherapy based on early response to VAMP chemotherapy and survival among children with favorable-risk Hodgkin lymphoma. JAMA, v. 307, n. 24, p. 2609-2616, 2012.

MORASSO, Gabriella et al. Evaluation of a screening programme for psychological distress in cancer survivors. Supportive care in cancer, v. 18, n. 12, p. 1545-1552, 2010.

MORLEY, John E.; THOMAS, David R.; WILSON, Margaret-Mary G. Cachexia: pathophysiology and clinical relevance. The American journal of clinical nutrition, v. $83, \mathrm{n}$. 4, p. 735-743, 2006.

MOSHER, Catherine E. et al. Associations between lifestyle factors and quality of life among older long-term breast, prostate, and colorectal cancer survivors. Cancer, v. 115, n. 17, p. 4001-4009, 2009.

MULLAN, Fitzhugh. Seasons of survival: reflections of a physician with cancer. The New England journal of medicine, v. 313, n. 4, p. 270, 1985.

MULROONEY, Daniel A. et al. Pilot study of vascular health in survivors of Hodgkin lymphoma. Pediatric blood \& cancer, v. 59, n. 2, p. 285-289, 2012. 
NATIONAL COMPREHENSIVE CANCER NETWORK, 2007 et al. NCCN Clinical Practice Guidelines in Oncology (NCCN Guidelines®): Hodgkin's Lymphoma. V1.2007. 2007.

NATIONAL COMPREHENSIVE CANCER NETWORK et al. NCCN Clinical Practice Guidelines in Oncology (NCCN Guidelines $\AA^{\circledR}$ ): distress Management. NCCN [Internet]. 2012.

NATIONAL COMPREHENSIVE CANCER NETWORK et al. NCCN Clinical Practice Guidelines in Oncology for Non-Hodgkin's Lymphomas. v 1.2015. 2015.

NUNES, Everson Araújo et al. Mecanismos pelos quais o treinamento de força pode afetar a caquexia em pacientes com câncer. Revista Brasileira de Prescrição e Fisiologia do Exercício, São Paulo, v.1, n.1, p.1-17, jan./fev. 2007. ISSN 1981-9900.

OKUYAMA, Toru et al. Factors correlated with fatigue in disease-free breast cancer patients: application of the Cancer Fatigue Scale. Supportive Care in Cancer, v. 8, n. 3, p. 215-222, 2000.

PACHMAN, Deirdre R. et al. Troublesome symptoms in cancer survivors: fatigue, insomnia, neuropathy, and pain. Journal of Clinical Oncology, v. 30, n. 30, p. 3687-3696, 2012.

PALLESEN, G. et al. Expression of Epstein-Barr virus latent gene products in tumour cells of Hodgkin's disease. The Lancet, v. 337, n. 8737, p. 320-322, 1991.

PARR, Christine L. et al. Body-mass index and cancer mortality in the Asia-Pacific Cohort Studies Collaboration: pooled analyses of 424519 participants. The lancet oncology, v. 11, n. 8, p. 741-752, 2010.

PAXTON, Raheem J. et al. Associations among physical activity, body mass index, and healthrelated quality of life by race/ethnicity in a diverse sample of breast cancer survivors. Cancer, v. 118, n. 16, p. 4024-4031, 2012.

PHILIP, Errol J. et al. Depression and cancer survivorship: importance of coping self-efficacy in post-treatment survivors. Psycho-Oncology, v. 22, n. 5, p. 987-994, 2013.

PRATT, Zachary L.; ZHANG, Jingzhu; SUGDEN, Bill. The latent membrane protein 1 (LMP1) oncogene of Epstein-Barr virus can simultaneously induce and inhibit apoptosis in $B$ cells. Journal of virology, v. 86, n. 8, p. 4380-4393, 2012.

PINTO, Cândida Assunção Santos; PAIS-RIBEIRO, José Luís. Sobrevivente de cancro: uma outra realidade!. Texto \& Contexto-Enfermagem, v. 16, n. 1, p. 142-148, 2007.

REEVES, Gillian K. et al. Cancer incidence and mortality in relation to body mass index in the Million Women Study: cohort study. Bmj, v. 335, n. 7630, p. 1134, 2007.

RIES, L. A. G. et al. SEER Cancer Statistics Review, 1975-2004. National Cancer Institute; Bethesda, MD: 2007. Available at: seer. cancer. gov/csr/1975-2001, 2007.

RODAK, Bernadette. Hematología: fundamentos y aplicaciones clínicas. Médica Panamericana, 2005.

RÜFFER, J. U. et al. Fatigue in long-term survivors of Hodgkin's lymphoma; a report from the German Hodgkin Lymphoma Study Group (GHSG). European Journal of Cancer, v. 39, n. 15, p. 2179-2186, 2003. 
RUTTEN, Iris JG et al. Loss of skeletal muscle during neoadjuvant chemotherapy is related to decreased survival in ovarian cancer patients.Journal of cachexia, sarcopenia and muscle, 2016.

SALIGAN, Leorey $\mathrm{N}$. et al. The biology of cancer-related fatigue: a review of the literature. Supportive Care in Cancer, v. 23, n. 8, p. 2461-2478, 2015.

SCHMAIER, Alvin H.; LAZARUS, Hillard M. (Ed.). Concise guide to hematology. John Wiley \& Sons, 2011.

SEIXAS, Raquel Jeanty de; KESSLER, Adriana; FRISON, Verônica Baptista. Atividade física e qualidade de vida em pacientes oncológicos durante o período de tratamento quimioterápico. Revista Brasileira de Cancerologia, Rio de Janeiro, v. 56, n. 3, p. 321-330, 2010.

SEMEDO, Deisa Salyse dos Reis Cabral. Descrição e compreensão das vivências de familiares de pessoas com doença oncológica e na identificação das dimensões do processo de resiliência, no contexto da realidade Cabo Verdiana. 2011.

SHA, Fei et al. Biomarkers for cancer-related fatigue and adverse reactions to chemotherapy in lung cancer patients. Molecular and clinical oncology, v. 3, n. 1, p. 163-166, 2015.

SIEGEL, Rebecca et al. Cancer statistics, 2011. CA: a cancer journal for clinicians, v. 61, n. 4, p. 212-236, 2011.

SIEGEL, Rebecca L.; MILLER, Kimberly D.; JEMAL, Ahmedin. Cancer statistics, 2015. CA: a cancer journal for clinicians, v. 65, n. 1, p. 5-29, 2015.

SIEGLER, Jason $\mathrm{C}$. et al. The effect of $\mathrm{pH}$ on fatigue during submaximal isometric contractions of the human calf muscle. European journal of applied physiology, v. 115, n. 3, p. 565-577, 2015.

SIMÃO, Roberto et al. A influência de três diferentes intervalos de recuperação entre séries com cargas para 10 repetições máximas. Rev. bras. ciênc. mov, v. 14, n. 3, p. 37-44, 2006.

SHEPPARD, Richard J.; BERGER, Jenna; SEBAG, Igal A. Cardiotoxicity of cancer therapeutics: current issues in screening, prevention, and therapy.Front Pharmacol, v. 4, p. 19, 2013.

SMETS, E. M. A. et al. The Multidimensional Fatigue Inventory (MFI) psychometric qualities of an instrument to assess fatigue. Journal of psychosomatic research, v. 39, n. 3, p. 315325, 1995.

SMITH, NANCY E.; TIMBY, BARBARA KUHN. Enfermagem médico-cirúrgica. Manole, 2005.

SPECTOR, Nelson. Abordagem atual dos pacientes com doença de Hodgkin. Rev Bras Hematol Hemoter, v. 26, n. 1, p. 35-42, 2004.

STACKHOUSE, Scott K.; REISMAN, Darcy S.; BINDER-MACLEOD, Stuart A. Challenging the role of $\mathrm{pH}$ in skeletal muscle fatigue. Physical therapy, v. 81, n. 12, p. 1897-1903, 2001.

SWERDLLOW, S. H.; CAMPO, Elias; HARRIS, N. Lee. WHO classification of tumours of haematopoietic and lymphoid tissues. France: IARC Press, 2008, 2008. 
TALARICO, Juliana Nery de Souza et al. Sintomas de estresse e estratégias de coping em idosos saudáveis. Rev. esc. enferm. USP, São Paulo, v. 43, n. 4, p. 803-809, Dec. 2009.

TERRERI, A. S. A. P.; GREVE, Júlia MD; AMATUZZI, Marco M. Avaliação isocinética no joelho do atleta. Rev Bras Med Esporte, v. 7, n. 2, p. 62-66, 2001.

TISDALE, Michael J. Cachexia in cancer patients. Nature Reviews Cancer, v. 2, n. 11, p. 862-871, 2002.

THIVAT, Emilie et al. Weight change during chemotherapy changes the prognosis in nonmetastatic breast cancer for the worse. BMC cancer, v. 10, n. 1, p. 1, 2010.

THIBAULT, Ronan; GENTON, Laurence; PICHARD, Claude. Body composition: why, when and for who? Clinical Nutrition, v. 31, n. 4, p. 435-447, 2012.

THOMAS, R. K. et al. Epidemiology and etiology of Hodgkin's lymphoma.Annals of Oncology-English Edition, v. 13, n. 4, p. 147-152, 2002.

VALERIANO, Ritielli de Oliveira. Desempenho muscular isocinético e nível de fadiga de indivíduos com Linfoma de Hodgkin em diferentes intervalos de recuperação. 2015.

VIEIRA, C. A. et al. Effects of rest interval on strength recovery in breast cancer survivors. International journal of sports medicine, v. 36, n. 07, p. 573-578, 2015.

VISOVSKY, Constance. Muscle strength, body composition, and physical activity in women receiving chemotherapy for breast cancer. Integrative cancer therapies, v. 5, n. 3, p. 183191, 2006.

WEISS, LAWRENCE M. et al. Epstein-Barr viral DNA in tissues of Hodgkin's disease. The American journal of pathology, v. 129, n. 1, p. 86, 1987.

WINTERS-STONE, Kerri M.; SCHWARTZ, Anna; NAIL, Lillian M. A review of exercise interventions to improve bone health in adult cancer survivors.Journal of cancer survivorship, v. 4, n. 3, p. 187-201, 2010.

WORLD HEALTH ORGANIZATION et al. The World health report: 2000: Health systems: improving performance. 2000.

WOLFE, Robert R. The underappreciated role of muscle in health and disease. The American journal of clinical nutrition, v. 84, n. 3, p. 475-482, 2006.

YAW, Yong Heng et al. Pattern of weight changes in women with breast cancer. Asian Pacific Journal of Cancer Prevention, v. 11, n. 6, p. 1535-1540, 2010. 


\section{APÊNDICE A}

\section{Perfil Socioeconômico e cultural}

1. Sexo:

(1) Masculino

(2) Feminino
(2)

(3) __ Dois

(4) __ Três

(5) ___ Acima de três

2. Cor da pele:
(1) branco
(2) ___ preto
(3) ___ pardo
(4) __ amarelo
(5) ___ indígena

\section{Estado civil:}
(1)
(2) solteiro(a)
(3) casado(a); união estável
(5) divorciado(a) viúvo(a)

4. Nível de escolaridade:
(1) Não-alfabetizado
(2) Fundamental incompleto
(3)
(4) Fundamental completo
(5) Médio incompleto
(6) __ Superior incompleto
(7) __ Superior completo
(8) Pós graduação

\section{Trabalha:}
(1)
(2) Sim

6. Número de dependentes:

(1) Nenhum

\section{Religião ou crença:}
(1) ___ Nenhuma
(2) __ Católica
(3) Evangélica
(4) __Espírita
(5) Budismo
(6) ___ Induísmo
(7) __ Judaísmo

8. Fumante:

(1)— Sim

9. Consome bebida alcóolica:

(1)

10. Fala-se de pessoas matutinas e vespertinas (as primeiras gostam de acordar cedo e dormir cedo, as segundas de acordar tarde e dormir tarde). Com qual desses tipos você se identifica?
(1) T__ Tipo matutino
(2) Mais matutino que vespertino
(3) __ Mais vespertino que matutino
(4) _ Tipo vespertino 


\section{APÊNDICE B \\ ANAMNESE}

Nome:

Sexo: ( ) Masculino ( ) Feminino

DN:

Idade:

1. Qual foi o seu tipo de linfoma de Hodgkin? Caso tenha sido esclerose nodular, por gentileza, marque o subtipo:

( ) Predominância linfocítica nodular

$\begin{array}{ll}\text { ( ) Linfoma de Hodgkin Clássico: } & \text { ( ) Esclerose nodular: （）Grau I ～( ) Grau II } \\ & \text { ( ) Riqueza linfocítica } \\ & \text { ( ) Celularidade mista } \\ & \text { ( ) Depleção linfocitária }\end{array}$

2. Estadio: ( ) I ( ) II $\quad$ ( ) III $\quad$ ( ) IV

3. Presença de sintomas B: ( ) Não

( ) Sim: ( ) Sudorese noturna

( ) Perda de mais de $10 \%$ do peso corporal

( ) Febre $\left(>38^{\circ} \mathrm{C}\right)$

4. Data do diagnóstico:

5. Idade no diagnóstico da doença:

6. Aonde os seus linfonodos apareceram primeiro?

( ) Pescoço

( ) Virilha

( ) Mediastino

( ) Outros:

7. Tipo de tratamento: ( ) QT exclusiva

( ) RT exclusiva

( ) Terapia combinada (QT + RT)

( ) Outros:

8. № e de sessões de QT:

№ sessões RT:

9. Protocolo utilizado no tratamento quimioterápico: ( ) ABVD ( ) MOPP

( ) Outro: 
10. Recidiva: ( ) sim ( ) não.

Em caso afirmativo, quanto tempo após 0 1ㅇ tratamento?

11. Você praticava atividade física antes do diagnóstico do linfoma? Descreva abaixo qual a atividade, frequência semanal e duração da sessão de treino.

12. Durante o tratamento, você praticou atividade física? ( ) sim ( ) não.

Em caso positivo, descreva abaixo qual a atividade, frequência semanal e duração da sessão de

treino.

13. Você sentiu algum efeito colateral durante o tratamento
( ) náusea
( ) alterações sexuais
( ) boca seca
( ) fadiga
( ) mucosite - ferida na boca
( ) nervosismo
( ) vômito
( ) constipação
( ) perda de apetite
( ) queda de cabelo
( ) diarreia
( ) coceira
( ) insônia
( ) falta de ar
( ) mudanças na pele
( ) ansiedade
( ) depressão
( ) febre e infecção
( ) outros:

14. Atualmente, você sente efeitos tardios, após o tratamento do linfoma? Descreva abaixo qual a atividade, frequência semanal e duração da sessão de treino.

( ) cardiopatia

( ) problemas pulmonares

( ) segunda neoplasia

( ) menopausa precoce

( ) fadiga

( ) complicações dentárias

( ) fibromialgia sono

( ) alterações sexuais

( ) perda da capacidade de concentração ( ) alterações sexuais

( ) Outros: 


\title{
APÊNDICE C
}

\section{Termo de Consentimento Livre e Esclarecido}

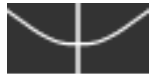 \\ UnB \\ UNIVERSIDADE DE BRASÍLIA \\ FACULDADE DE EDUCAC̄ÃO FÍSICA \\ CAMPUS UNIVERSITÁRIO DARCY RIBEIRO - BRASÍLIA/DF \\ Telefone: (61) 3107-2500
}

\section{Termo de Consentimento Livre e Esclarecido}

Você está sendo convidado(a) a participar, como voluntário(a), da pesquisa "Desempenho muscular isocinético e nível de fadiga em indivíduos com linfoma de Hodgkin em diferentes intervalos de recuperação", cujo objetivo é comparar os efeitos agudos de diferentes intervalos de recuperação nas respostas neuromusculares e níveis de fadiga de indivíduos com linfoma de Hodgkin, antes, durante e após um ano do período de quimioterapia (QT). A pesquisa justifica-se, pois grande parte dos indivíduos em tratamento reportam sintomas relacionados à fadiga, que persistem em muitos casos, mesmo após o tratamento. A redução da capacidade para o trabalho e a diminuição das habilidades para a realização das tarefas da vida diária frequentemente são acompanhadas pelo desgaste e cansaço, condições típicas da fadiga relacionada ao câncer. Por sua vez, o exercício tem apresentado benefícios fisiológicos e psicológicos sobre alguns efeitos associados ao tratamento, incluindo, mudanças positivas nos níveis de fadiga. No entanto, são escassos os estudos que analisaram o impacto do exercício resistido sobre o ganho de força muscular e fadiga, de pacientes com linfoma de Hodgkin em tratamento.

Este projeto contém seis fases, sendo uma antes do início da quimioterapia $\left(\mathrm{x}_{0}\right)$, uma após a segunda sessão de QT $\left(\mathrm{x}_{1}\right)$, uma após a quarta sessão de QT $\left(\mathrm{x}_{2}\right)$, uma ao final da QT ( $\left.\mathrm{x}_{3}\right)$, uma após seis meses do término da QT $\left(\mathrm{x}_{4}\right)$ e a última após 12 meses do término da QT (x5). Você poderá optar em participar em qualquer uma das fases. Todas as fases serão realizadas na Faculdade de Educação Física da Universidade de Brasília. Para cada fase serão necessários três encontros, com $72 \mathrm{~h}$ de intervalo. Nesses encontros, você realizará um teste físico, um exame de composição corporal e preencherá alguns questionários. Você será supervisionado durante todo o processo de intervenção por um profissional de educação física.

Você receberá todos os esclarecimentos necessários antes e durante a pesquisa e lhe asseguramos que seu nome não será divulgado, sendo mantido o mais rigoroso sigilo com a omissão total de quaisquer informações que permitam identificálo(a). O seu transporte, quando necessário, será feito pelo pesquisador responsável. O tempo de permanência no laboratório para a realização dos testes está estimado em duas horas e os horários de sua participação serão previamente agendados, 
respeitando os intervalos acima citados, bem como, a sua disponibilidade. Você deverá estar nos locais designados nos dias e horários marcados e informar aos pesquisadores qualquer desconforto que por acaso venha a perceber.

Este estudo não lhe acarretará gastos. Em princípio, o teste físico não possui contraindicação, porém, pode gerar dor muscular tardia, que desaparece em poucos dias. Fica também garantida a indenização diante de eventuais danos, comprovadamente, decorrentes da participação na pesquisa. Este estudo não deverá ser aplicado em pessoas que estejam em tratamento antes do início do estudo ou que sejam portadoras de doença cardiovascular, doença respiratória crônica ou aguda, hipertensão, diabetes mellitus e imunidade não controladas, doença mental, infecção, e comprometimento musculoesquelético.

Com os resultados deste estudo poderemos obter informações sobre os efeitos de diferentes intervalos de recuperação no desempenho muscular isocinético em indivíduos com linfoma de Hodgkin, antes, durante e após o tratamento quimioterápico, definindo seus benefícios ou não para esta população, sendo este conhecimento útil aos profissionais da área da saúde. Os dados e materiais utilizados na pesquisa ficarão sob a guarda dos pesquisadores por um período de, no mínimo, cinco anos e após isso serão destruídos ou mantidos na instituição.

As informações obtidas neste experimento poderão ser utilizadas como dados de pesquisa científica, podendo ser publicadas e divulgadas, sendo resguardada a sua identidade. Você poderá ter acesso aos seus resultados, por intermédio do pesquisador responsável. A pesquisa será imediatamente suspensa, caso o pesquisador perceba algum risco ou danos a sua saúde, tanto os previstos quanto os não previstos, neste termo. No improvável dano físico resultante da participação neste estudo, o tratamento será viabilizado no local mais próximo e apropriado de assistência médica, porém, nenhum benefício especial será concedido, para compensação ou pagamento de um possível tratamento.

A sua participação nesta pesquisa é voluntária, isto é, não há pagamento por sua colaboração. Você estará livre para negá-la ou para, em qualquer momento, desistir da mesma, se assim desejar. No caso de aceitar fazer parte do estudo, após ter lido e esclarecido sobre as informações acima, você deverá assinar ao final deste documento, que está em duas vias. Uma delas é sua e a outra ficará com o pesquisador responsável. Todas as folhas deverão ser rubricadas pelo voluntário da pesquisa ou seu responsável e pelo pesquisador responsável.

Este projeto foi aprovado pelo Comitê de Ética em Pesquisa da Faculdade de Ciências da Saúde da Universidade de Brasília e pelo Comitê de Ética em Pesquisa/FEPECS-SES-DF. O CEP é composto por profissionais de diferentes áreas cuja função é defender os interesses dos participantes da pesquisa em sua integridade e dignidade e contribuir no desenvolvimento da pesquisa dentro de padrões éticos. Em caso de dúvida ou reclamação, você poderá entrar em contato com a pesquisadora responsável, Ritielli de Oliveira Valeriano, no telefone (61) 8403 2730 ou (61) 3107 2511, com o Comitê de Ética e Pesquisa da Faculdade de Ciência da Saúde da UnB (CEP/FS), no telefone (61) 31071947 ou com o Comitê de Ética em Pesquisa/FEPECS-SES-DF, no telefone (61) 33254955. 
Data:

Assinatura do participante

Nome:

RG:

Endereço:

Fone: ( )

Data:

Lorena Cruz Resende

1

Pesquisadora responsável 


\section{ANEXO I}

\section{Inventário Multidimensional de Fadiga}

(Versão brasileira do MFI)

\section{Instruçôes:}

Com base nas seguintes declaracōes, gostariamos de ter uma idéia de como vocể tem se sentido ultimamente.

Vejamos, por exemplo, a afirmação:

\section{"SINTO-ME DESCONTRAÍDO/A (À VONTADE)"}

Se vocể acha que esta afirmação é inteiramente verdadeira e que você tem realmente se sentido descontraido/a ultimamente, coloque um X $(\mathrm{x})$ no quadrado mais à esquerda, como a seguir:

sim, é verdade $冈 1 \square 2 \square 3 \square 4 \square 5$ não, não é verdade

Quanto mais discordar da afirmação, mais o $\mathrm{X}(\mathrm{x})$ deverá ser colocado na direção de "não, não é verdade". Não deixe em branco nenhuma afirmaçăo e coloque apenas um $\mathrm{X}(\mathrm{x}) \mathrm{em}$ um único quadrado para cada afimaçăo.

\begin{tabular}{|c|ll|l|l|l|l|l|c|}
\hline 1 & Sinto-me em forma. & $\begin{array}{l}\text { sim, é } \\
\text { verdade }\end{array}$ & $\square 1$ & $\square 2$ & $\square 3$ & $\square 4$ & $\square 5$ & $\begin{array}{c}\text { não, não é } \\
\text { verdade }\end{array}$ \\
\hline 2 & $\begin{array}{l}\text { Fisicamente, me sinto capaz de } \\
\text { fazer poucas coisas. }\end{array}$ & $\begin{array}{l}\text { sim, é } \\
\text { verdade }\end{array}$ & $\square 1$ & $\square 2$ & $\square 3$ & $\square 4$ & $\square 5$ & $\begin{array}{c}\text { não, não é } \\
\text { verdade }\end{array}$ \\
\hline 3 & $\begin{array}{l}\text { Sinto-me muito ativo/a. } \\
\text { sim, é } \\
\text { verdade }\end{array}$ & $\square 1$ & $\square 2$ & $\square 3$ & $\square 4$ & $\square 5$ & $\begin{array}{c}\text { não, não é } \\
\text { verdade }\end{array}$ \\
\hline 4 & $\begin{array}{l}\text { Tenho vontade de fazer todo o tipo } \\
\text { de coisas agradáveis. }\end{array}$ & $\begin{array}{l}\text { sim, é } \\
\text { verdade }\end{array}$ & $\square 1$ & $\square 2$ & $\square 3$ & $\square 4$ & $\square 5$ & $\begin{array}{c}\text { não, não é } \\
\text { verdade }\end{array}$ \\
\hline 5 & $\begin{array}{l}\text { Sinto-me cansado/a. } \\
\text { sim, é } \\
\text { verdade }\end{array}$ & $\square 1$ & $\square 2$ & $\square 3$ & $\square 4$ & $\square 5$ & $\begin{array}{c}\text { não, não é } \\
\text { verdade }\end{array}$ \\
\hline 6 & $\begin{array}{l}\text { Acho que faço muitas coisas num } \\
\text { dia. }\end{array}$ & $\begin{array}{l}\text { sim, é } \\
\text { verdade }\end{array}$ & $\square 1$ & $\square 2$ & $\square 3$ & $\square 4$ & $\square 5$ & $\begin{array}{c}\text { não, não é } \\
\text { verdade }\end{array}$ \\
\hline 7 & $\begin{array}{l}\text { Quando estou fazendo alguma coisa, } \\
\text { consigo concentrar-me no que estou } \\
\text { fazendo. }\end{array}$ & $\begin{array}{l}\text { sim, é } \\
\text { verdade }\end{array}$ & $\square 1$ & $\square 2$ & $\square 3$ & $\square 4$ & $\square 5$ & $\begin{array}{c}\text { não, não é } \\
\text { verdade }\end{array}$ \\
\hline
\end{tabular}




\begin{tabular}{|c|c|c|c|c|c|c|c|c|}
\hline 8 & Fisicamente, agüento muita coisa. & $\begin{array}{l}\text { sim, é } \\
\text { verdade }\end{array}$ & $\square 1$ & $\square 2$ & $\square 3$ & $\square 4$ & $\square 5$ & $\begin{array}{c}\text { não, não é } \\
\text { verdade }\end{array}$ \\
\hline 9 & Detesto ter coisas para fazer. & $\begin{array}{l}\text { sim, é } \\
\text { verdade }\end{array}$ & $\square 1$ & $\square 2$ & $\square 3$ & $\square 4$ & $\square 5$ & $\begin{array}{c}\text { não, não é } \\
\text { verdade }\end{array}$ \\
\hline 10 & $\begin{array}{l}\text { Acho que faço muito pouca coisa } \\
\text { num dia. }\end{array}$ & $\begin{array}{l}\text { sim, é } \\
\text { verdade }\end{array}$ & $\square 1$ & $\square 2$ & $\square 3$ & $\square 4$ & $\square 5$ & $\begin{array}{c}\text { não, não é } \\
\text { verdade }\end{array}$ \\
\hline 11 & Consigo me concentrar bem. & $\begin{array}{l}\text { sim, é } \\
\text { verdade }\end{array}$ & $\square 1$ & $\square 2$ & $\square 3$ & $\square 4$ & $\square 5$ & $\begin{array}{l}\text { não, não ć } \\
\text { verdade }\end{array}$ \\
\hline 12 & Estou descansado/a. & $\begin{array}{l}\text { sim, é } \\
\text { verdade }\end{array}$ & 口1 & $\square 2$ & $\square 3$ & $\square 4$ & $\square 5$ & $\begin{array}{c}\text { não, não é } \\
\text { verdade }\end{array}$ \\
\hline 13 & $\begin{array}{l}\text { Tenho que em esforcar muito para } \\
\text { me concentrar nas coisas. }\end{array}$ & $\begin{array}{l}\text { sim, é } \\
\text { verdade }\end{array}$ & 1 & $\square 2$ & $\square 3$ & $\square 4$ & $\square 5$ & $\begin{array}{l}\text { não, não é } \\
\text { verdade }\end{array}$ \\
\hline 14 & $\begin{array}{l}\text { Fisicamente, sinto-me em más } \\
\text { condicöes. }\end{array}$ & $\begin{array}{l}\text { sim, é } \\
\text { verdade }\end{array}$ & $\square 1$ & $\square 2$ & a3 & $\square 4$ & $\square 5$ & $\begin{array}{l}\text { não, não é } \\
\text { verdade }\end{array}$ \\
\hline 15 & Tenho muitos planos. & $\begin{array}{l}\text { sim, é } \\
\text { verdade }\end{array}$ & D1 & $\square 2$ & a3 & 口4 & D5 & $\begin{array}{c}\text { não, não é } \\
\text { verdade }\end{array}$ \\
\hline 16 & Canso-me facilmente. & $\begin{array}{l}\text { sim, é } \\
\text { verdade }\end{array}$ & $\square 1$ & $\square 2$ & $\square 3$ & $\square 4$ & $\square 5$ & $\begin{array}{c}\text { não, não é } \\
\text { verdade }\end{array}$ \\
\hline 17 & Consigo fazer pouca coisa. & $\begin{array}{l}\text { sim, é } \\
\text { verdade }\end{array}$ & 1 & $\square 2$ & 口3 & 口4 & 口5 & $\begin{array}{l}\text { não, não é } \\
\text { verdade }\end{array}$ \\
\hline 18 & Não tenho vontade de fazer nada. & $\begin{array}{l}\text { sim, é } \\
\text { verdade }\end{array}$ & 口1 & $\square 2$ & a3 & $\square 4$ & 口5 & $\begin{array}{l}\text { não, não é } \\
\text { verdade }\end{array}$ \\
\hline 19 & Distraio-me facilmente. & $\begin{array}{l}\text { sim, é } \\
\text { verdade }\end{array}$ & D1 & $\square 2$ & a3 & $\square 4$ & D5 & $\begin{array}{c}\text { não, não é } \\
\text { verdade }\end{array}$ \\
\hline 20 & $\begin{array}{l}\text { Fisicamente, sinto-me em excelente } \\
\text { condicão. }\end{array}$ & $\begin{array}{l}\text { sim, é } \\
\text { verdade }\end{array}$ & $\square 1$ & $\square 2$ & a3 & $\square 4$ & $\square 5$ & $\begin{array}{l}\text { não, não ć } \\
\text { verdade }\end{array}$ \\
\hline
\end{tabular}

Muito obrigado pela sua colaboração 


\section{ANEXO II}

\section{Termômetro de Distress - Versão 1.0}

Primeiramente, circule um número de 0 a 10 que melhor descreve a quantidade de distress que você tem experimentado na semana passada incluindo o dia de hoje.

\section{Extremo Distress}

Sem Distress

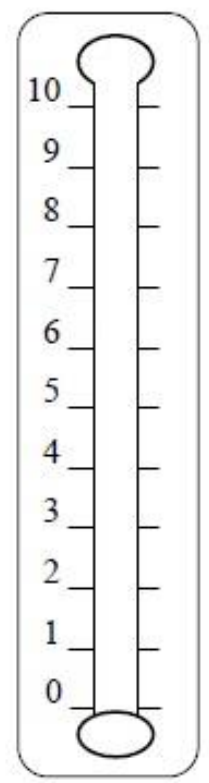

Indique a seguir, se algum desses itens tem sido um problema para você na última semana, incluindo o dia de hoje. Certifique-se de assinalar Sim (S), Não (N) ou Não se aplica (Na) em cada item.

S N Na Problemas Práticos

() () () Cuidar de criança

() () () Cuidar da casa

S N Na Problemas Físicos

() () () Plano de saúde/

() () () Tranceiro

() () () Aparência
() () () Tomar banho/se vestir

() () () Respiração

() () () Trabalho/escola

Problemas Familiares

() () () Filhos

() () () Mudanças ao urinar

() () () Constipação

() () () Diarréia

() () () Alimentação

() () () Fadiga

() () () Companheiro(a)

() () () Sentindo-se inchado

() () () Febre Problemas Emocionais

() () () Depressão

() () () Dar uma volta/circular

() () () Indigestão

() () () Medos

() () () Memória/concentração

() () () Nervosismo

() () () Tristeza

() () () Preocupação

() () () Perda do interesse em atividades usuais

() () () Mucosite/afta

() () () Náusea

() () () Nariz seco/congestionado

() () () Dores

() () () Sexual

() () () Pele seca/coceira

() () () Dormir

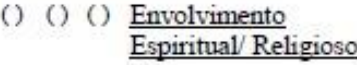

Outros Problemas: 
